\title{
Accident Law for Egalitarians
}

\author{
Ronen Avraham \\ Assistant Professor of Law, Northwestern University
}

Issa Kohler-Hausmann,

JD \& PhD candidate, Northwestern University

We thank Robert Burns, Jules Coleman, Hanoch Dagan, David Dana, Richard Epstein, Ofer Grosskopf, Gregory Keating, Andy Kopplman, Allegra McLeod, Ariel Porat, Danny Statman, Charles Taylor, Ernest Weinrib, and the participants of the Northwestern University School of Law Faculty Workshop, the Northwestern University School of Law Zodiac Forum and Tel Aviv University Faculty of Law Faculty Seminar. 


\section{Accident Law for Egalitarians}

$\underline{\text { Table of Contents }}$

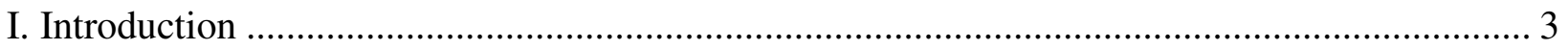

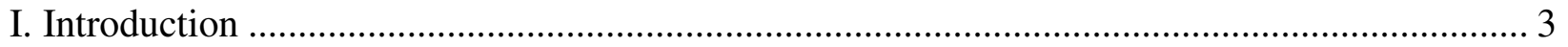

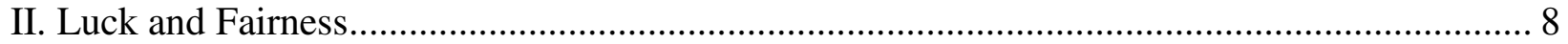

III. Luck in Distributive Justice ................................................................................... 11

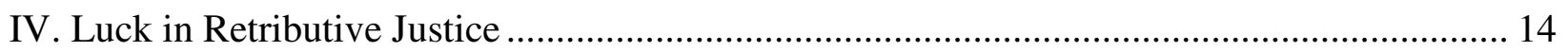

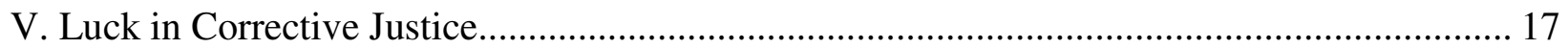

VI. Luck, Fairness and The Treatment of Equally Careless Actors .......................................... 20

VII. Luck, Fairness and The Treatment of Equally Blameless Victims .................................. 30

How and Why are Corrective and Distributive Justice Distinct? ....................................... 32

Harms by Agents vs. Harms by Nature ..................................................................... 33

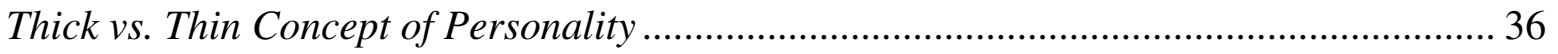

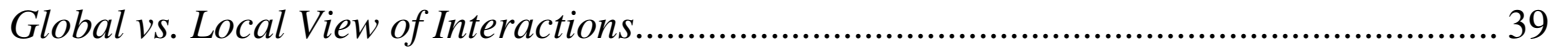

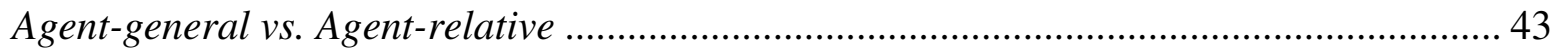

VIII. Practical Reasons: The Isolation of CJ Creates Unfair Outcomes.................................... 46

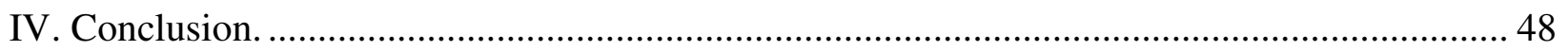




\section{Accident Law for Egalitarians}

\section{Introduction}

For egalitarians fairness requires that, as much as possible, like cases be treated alike. This paper is motivated by a commitment to egalitarian fairness, and by a few simple intuitions about the role of luck in determining outcomes in accident law: both in terms of liability for carelessness and compensation for misfortune.

Egalitarians hold that all persons are alike in at least one relevant sense, we stand as moral equals to one another with an equal interest in being responsible for our lives. Fairness requires our equality and responsibility be respected in social interactions and institutions. The concept of luck has been used by many egalitarians as a way of giving content to fairness by differentiating between those benefits and burdens which result from informed choice from those that result from fate or fortune. Many egalitarians explore negating luck as a way of expressing their commitments to treating people as moral equals whose lives should, as much as possible, be a reflection of choice as opposed to the afflictions of chance. This is the normative premise of our paper, we call it the "fairness test". As we explain more below, the fairness test assess whether luck is allowed to play an unjustified role in compensation for similar losses or liability for similar wrongs.

Many egalitarian political theorists have also recognized, if not defended, the notion of distinct forms of justice, namely corrective, retributive, and distributive. Corrective justice concerns the fair terms of rectification for largely unintentional private wrongs, such as bilateral accidents, and the losses that flow from such private wrongs. Retributive justice concerns the fair terms of punishment for public wrongs, intentional acts of harm to others which offend the social order, according to principles of harm and moral blameworthiness. Distributive justice concerns the fair terms of allocation of social burdens and benefits in terms of the design of core social and economic institutions. Although theorists of these different forms of justice have been concerned with negating unfair luck inside the operations of each form of justice, there has been little attention to the way in which luck operates to sort cases into each form of justice. We claim that there is a significant way in which luck operates to subject different people to principles of corrective, retributive, and distributive justice which flies in the face of the egalitarian value of fairness: a commitment to treating people as moral equals with like interests in being responsible for their own lives. Our claim is that there is a way that egalitarian fairness transcends the 
analytical boundaries of different forms of justice. Thus we think that the maintaining strict analytical boundaries between RJ, DJ and CJ fails the "fairness test" and is therefore unjustified.

In order to motivate this intuition, consider the following cases. The first three describe victims of misfortune, the next four describe doers of careless or non-careless actions.

Amy is 20 years old. She became blind as a result of a car accident. It was the other driver's fault. If Amy lives in a no-fault state, a state which administers automobile accident losses via regulated insurance markets, then she is expected to receive a fixed sum of money calculated to compensate her for her injuries and associated medical bills from her insurance company. If she does not live in a no-fault state then she is expected to collect, under most circumstances, a larger fixed sum of money which will compensate her for her injuries and associated medical bills (possibly, in addition, pain and suffering and/or punitive damages) from the other driver or her insurance company.

Bill is 20 years old. He became blind as a result of a car accident. The other driver was at fault yet under-insured. Specifically, the other driver's insurance limit was at the state mandated minimum. The other driver has no other assets to collect from, and therefore Bill can recover no more than the policy limit, which will be much less than the fixed sum received by Amy.

Carol is 20 years old. She became blind as a result of a congenital disease, like meningitis. At best, if she is well insured, she will have her basic medical costs covered. At worst she will not be able to get private insurance and will turn to federal programs such as SSI and Medicaid, and be able to get some minimal medical coverage and perhaps a relatively low monthly disability benefit.

Consider the following drivers. David is an attentive, careful driver. Every day he leaves for work on time and obeys the speed limit and other norms of safe driving. One morning he is rushed, speeds to work, and on the way causes an accident because of his speeding. David hits Amy and is found liable for her ensuing blindness.

Emmanuel speeds to work recklessly everyday. He sleeps in and leaves late. In his haste he cuts off other cars, runs Stop signs, speeds, and otherwise flouts the norms of safe driving on a daily basis. Emmanuel never gets into an accident, partially because other drivers accommodate his reckless driving by slowing down and exercising extra caution in his presence. On the morning David hits Amy, Ernie would have hit another driver had it not been for the fortuitous 


\section{Accident Law for Egalitarians}

intervention of a bird which caused the other driver to swerve, thereby preventing him from hitting the other driver's car. Emmanuel never bears any cost for his reckless driving.

Francie is a careful driver who never exceeds the speed limit or violates norms of careful driving. Every day she takes the same route to work as Emmanuel, and exercises extra caution because of Emmanuel's unpredictable driving.

Case $\mathrm{A}, \mathrm{B}$, and $\mathrm{C}$ have one major thing in common: they all suffered the loss of their eyesight at no fault of their own. In so far as the loss was not the fault of the individual who suffered it, these losses are, in a relevant normative sense, alike. Yet each person ends up with very different access to compensation for his or her loss. As mentioned above, Amy will end up with full compensation for medical costs, lost income, cost of accommodating her life to blindness, and if she lives in a "negligence" state, as opposed to a "no-fault" state, she may even be awarded pain and suffering and punitive damages. Bill will end up with possibly only a fraction of his medical bills paid from the underinsured motorist who hit him; he will be left to bear the remainder of the costs of his injury himself. Carol, if she is uninsured at the time her disease is discovered, will be uninsurable in the private market for insurance as it relates to the disease that caused her blindness. Both Bill and Carol might be able to get some monthly benefits through a combination of public programs (i.e. Medicare, SSDI, SSI, and if their income drops Medicaid).

The decisive factor determining what compensation will be available to $\mathrm{A}, \mathrm{B}$, or $\mathrm{C}$ is something outside of his or her control. It is whether or not each can attribute the 'cause' of his or her blindness to the negligence of another person, and the level of insurance the other driver carried at the time of the accident. (We ignore for now the level of insurance that they carried). We commonly talk about those factors which are outside our control as luck. Therefore, the compensation available to these equally innocent victims is largely due to luck.

Cases D and E have one major thing in common: they both violated the duty of care established by the norms of safe driving. The decisive factor that renders D liable for massive damages, and not $\mathrm{E}$, is something outside of both of their control — the position of other drivers, and one little bird-factors we understand as luck. In fact, F, the consistently careful driver, is treated the same as the E, the consistently careless driver. Therefore, the liability imposed on these equally faulty drivers ( $D \& E$ ) is largely due to luck, as is the equal treatment of unequally careless drivers $(\mathrm{E} \& \mathrm{~F})$. 
Are cases A, B, and C-and D and E-alike in a normatively relevant sense such that their differential treatment is unjustified? Many of us would share the moral intuitions that there is something counterintuitive about the dissimilar outcomes illustrated by these cases given their relevant similarities. We think it fails the fairness test: luck and nothing more determines dissimilar outcomes of otherwise similar cases. Yet, those familiar with the distinction between corrective justice and its institutional form of tort law, and other forms and institutions of justice, are also all familiar with reasons explaining these differential outcomes as both normal and acceptable. These reasons have to do with the distinction between corrective and distributive justice with respect to cases $\mathrm{A}, \mathrm{B}$ and $\mathrm{C}$, and the distinction between retributive and corrective justice with respect to cases $\mathrm{D}$ and $\mathrm{E}$.

Most theorists of tort law would maintain that the differential outcomes illustrated by cases A through $\mathrm{F}$ are not necessarily unfair. Such theorists would explain the differential outcomes with reference to the distinction between corrective justice and other forms of justice, namely distributive and retributive. Cases A, B and D are subject to the principles of corrective justice, whereas cases $\mathrm{C}$ and $\mathrm{E}$ are subject to the principles of distributive and retributive justice, respectively. Retributive justice $(\mathrm{RJ})$ is concerned with the adequate response to those who, through intentional harms to others, create an imbalance in the social order which must be addressed by actions against that violator in proportion to moral blameworthiness; it is a theory typically associated with criminal law. Corrective justice $(\mathrm{CJ})$ is concerned with rectification of losses attributable to 'private' wrongs and the associated (typically) unintended harmful consequences; it is a theory associated with tort law. Distributive justice (DJ) is concerned with the allocation of social benefits and duties among members of a political community; it is a theory which is associated with tax and transfer laws. Traditionally, RJ, CJ and DJ have been considered distinct forms of justice operating on different spheres of human affairs, ${ }^{1}$ just as their respective areas of law operate largely independently of one another.

Accordingly, cases A, B and D are subject to corrective justice because they involve losses suffered from and caused by human agency. Cases $\mathrm{C}$ and $\mathrm{E}$ fall to distributive and retributive justice (respectively) because they cannot be so connected to human agency. Case $\mathrm{C}$ (meningitis)

\footnotetext{
${ }^{1}$ To use Aristotle's famous metaphore, corrective enforces an arithmetic equality in transactions such that no individual may gain or lose their due according to the norms of interaction; distributive justice enforces a geometric proportion such that each citizen contributes and receives a portion of social resources according some merit, however social resources and merit are defined.
} 


\section{Accident Law for Egalitarians}

represents loss caused by, perhaps a cruel God or the vicissitudes of nature, but by no agent in particular; case $\mathrm{E}$ (the reckless driver who hits no one) represents a wrong involving losses to no one in particular. The distinction between CJ, DJ and RJ creates a sorting rule by which cases of misfortune and misconduct are placed under the auspices of one or another form of justice. These cases are subject to distinct forms of justice, and that is what produces differential patterns of cost bearing.

The conviction motivating this paper is that the theoretical claims which support these distinctions between forms and institutions of justice violate a basic notion of fairness which transcends the bounds of either CJ, DJ or RJ. Surprisingly, many tort theorists not only dismiss the idea that the distinction between forms of justice creates an unfair pattern of responsibility (and the cost bearing it entails), but rather defend the distinction between $\mathrm{CJ}$ and $\mathrm{DJ}$ and RJ as embodying a basic commitment to fairness. We think not.

Corrective, retributive and distributive justice share a comparable commitment to egalitarian fairness by negating luck as a significant determinant of the rewards and burdens in peoples' lives inside their respective spheres of justice. However, we argue that maintaining a commitment to categorical distinctions between these forms of justice paradoxically violates egalitarian fairness. In other words, the strict separation between CJ, RJ and DJ fails the fairness test because luck sorts cases between spheres of justice, creating dissimilar outcomes for similar cases.

Section II briefly fleshes out the concept of luck as essentially a normative designation in a substantive theory of fairness which respects both equality and responsibility. Sections III and IV identify the role of luck in both DJ and RJ. We will highlight how both DJ and RJ struggle with the same question: what types of luck must be negated to realize the moral equality of persons in a society? Our main point in those Sections is that, with some qualifications, in both theories (RJ and DJ) the conceptions of fairness are determined through the paradigm that brute luck (to borrow Dworkin's term indicating luck not attributable to choice) should be negated, while option luck (that which is the upshot of informed choice) should not be. ${ }^{2}$ In Section V we will argue that these conceptions of fairness from distributive and retributive justice cannot be completely excluded from evaluation of fairness in corrective justice. While luck does play a major role in the realm of $\mathrm{CJ}$ especially in the various doctrines related to causation, its role is

\footnotetext{
${ }^{2}$ The terms "brute luck" and "option luck" will be developed and further defined, see supra Section III.
} 
totally internal to the operations of CJ. There is no similar attempt to negate the arbitrariness of luck with respect to whether cases should be subject to CJ institutions (e.g. tort law) in the first place. In Sections VI and VII we argue that two ways in which the isolation of CJ principles from both DJ and RJ lead to an unfair operation of luck in the determination of liability for equally careless actors, and compensation for equally blameless victims.

In Section VII. A. we argue that neither theoretical nor practical arguments for the acoustic separation of these principles justify the costs to fairness this distinction creates. ${ }^{3}$ We explore the justifications that (mainly CJ) theorists have presented for maintaining the distinction between CJ and DJ. These include: that DJ is about fair allocation of societal resources whereas CJ is about rectifying private wrongs; that DJ requires thick whereas $\mathrm{CJ}$ requires thin concept of personality; that DJ operates on a global view of the interactions, whereas CJ's view is local; and that DJ generates general duties or reasons for action, whereas CJ imposes specific duties on particular individuals to undertake particular actions.

We argue that these distinctions, while interesting, lack normative significance. Maintaining those distinctions preserves $\mathrm{CJ}$ as a distinct justice-machine, yet at the expense of global fairness. Indeed, maintaining these distinctions shows theorists' commitment to CJ and not to fairness, or at least so we argue.

\section{Luck and Fairness}

Our motivation in this project is simple: fairness requires that, as much as possible, like cases be treated alike, and cases that differ upon normatively relevant vectors be treated differently. The contours of CJ, DJ and RJ (and the contours of their political or institutional manifestations: tort law, tax and social security law, and criminal law respectively) are human constructs that must derive their legitimacy from external, pragmatic or moral, foundations. Either notions of cost and efficiency, or normative notions such as fairness, equality and responsibility, must inform the contours of these theories of justice, and their institutional manifestations. At this point, we ignore costs and efficiency considerations and focus on fairness. As we show at length below, major theorists have a dual commitment as their starting point. One is an egalitarian commitment to fairness in the sense of negating the role of (some) luck in

\footnotetext{
${ }^{3}$ We use the term "acoustic" separation to denote the construction of analytical or conceptual barriers between forms of justice which prevent principles from one form of justice, say RJ or DJ, from seeping into considerations of fairness in another form of justice, say CJ.
} 


\section{Accident Law for Egalitarians}

determining one's burdens and rewards. We share this commitment. What we do not share is a separate, unnecessary in our view, commitment to maintaining an acoustic separation between CJ and DJ or RJ, when by doing so it fails the fairness test. ${ }^{4}$ It seems odd to us to have a theoretical pre-commitment to a distinction between forms of justice. We, on the other, have just one commitment, to fairness.

The costs to fairness arise, in our view, from the role that luck and control play in our lives. Cases A through E demonstrate how otherwise equal actors face different outcomes because of something outside of their control, something which is mere luck. We argue that if one accepts the notion that luck should not determine people's desert and responsibility, then the distinction between $\mathrm{CJ}$ and DJ and RJ must be revisited.

In the following three sections we will discuss the role of control and luck in corrective, distributive and retributive justice and their respective substantivenotions of fairness. In doing so, we employ Ronald Dworkin's terms "brute luck" and "option luck", not necessarily as an endorsement of his theory of DJ, but rather because the terms usefully illustrae the normative distinctions various theories make — as a matter of fairness - between personal responsibility and undeserved misfortune. Dworkin defines "option luck" as "a matter of how deliberate and calculated gambles turn out" whereas "brute luck" is "a matter of how risks fall out that are not in that sense deliberate gambles"5 We find the brute-option luck distinction a useful heuristic device for understanding how different theorists of justice make determinations between personal and collective responsibility according to the substantive criterion of fairness he or she proposes. We will not take a position on where the line between brute and option luck should be drawn, we employ the distinction to argue that wherever that line is found, fairness requires we negate the unacceptable operation of brute luck.

\footnotetext{
${ }^{4}$ For a description of the categorical distinction between CJ and DJ, see Ernest Weinrib, The Idea of Private Law 62-70 (Harvard University Press 1995). Although not all corrective justice theorists see CJ as categorically distinct from DJ, most see the inability of a CJ theory to distinguish itself from DJ as a fatal theoretical flaw for any plausible conception of CJ. See Jules Coleman, Second Thoughts and Other First Impressions, in Analyzing Law: New Essays in Legal Theory 257-321, at 307-316 (Brian Bix ed., University Press 1998); Stephen Perry, The Distributive Turn: Mischief, Misfortune and Tort Law, in Analyzing Law: New Essays in Legal Theory 141-162 (Brian Bix ed., University Press 1998). Peter Benson, The Basis of Corrective Justice and Its Relation to Distributive Justice, 77 Iowa L. Rev. 515, 528 (1992); Arthur Ripstein, Equality, Responsibility and the Law (Cambridge University Press 1999).

${ }^{5}$ Ronald Dworkin, What is Equality. Part 2: Equality of Resources, Philosophy \& Public Affairs Vol. 10 Issue 4, 283, 293 (1981).
} 
Corrective, retributive and distributive justice share a common egalitarian commitment that fairness requires treating people as equals. In general terms, fairness encompass the moral intuition, often expressed in egalitarian theories of justice, of persons as moral equals with a capacity and interest in being responsible for their lives. We will claim that all the forms of justice — corrective, retributive or distributive — are motivated by a concern for fair treatment which means respecting the idea of persons as moral equals, and as agents who deserve and desire to be responsible for their life choices and outcomes.

Responsibility is both an aspect and a demand of the moral equality of persons, because it is a necessary concept to realize our shared aspiration to call our deeds and lives our own in a community of equals. ${ }^{6}$ Responsibility is what allows us to be authors of our own lives and realize our equal capacities for a sense of justice and "to have, to revise, and to rationally pursue a conception of the good", to borrow Rawls' terms. ${ }^{7}$

We are not arguing that brute luck and option luck are the best way to understand DJ, RJ, or CJ. We only use luck as a heuristic device to talk about substantive notions of what we owe each other. In DJ, egalitarians debate the substantive question of how to realize a commitment to equality and responsibility by talking about what sorts of luck we should collectively negate to assure all persons have the same opportunity to pursue a full life. ${ }^{8}$ In RJ, philosophers debate the question of moral responsibility by talking aboutwhether letting luck deermine the moral blameworthiness of a person is acceptable. ${ }^{9}$ In $\mathrm{CJ}$, theorists debate how to properly formulate a concept of responsibility for (largely unintended) harmful actions or outcomes that grounds a duty to compensate in morally acceptable terms. In all these theories of justice, the line between luck and responsibility is not determined by an empirical or metaphysical inquiry into whether or not something was "really" due to luck or under human control. Rather, it is determined by a normative argument about what sorts of things are reasonable to expect from people living in a

\footnotetext{
${ }^{6}$ Jules Coleman makes a similar point about the importance of a concept of responsibility in a liberal society, not merely in terms of accountability, but as "the core of the liberal ideal: that if we are to have a certain concept of the individual as an agent, as a being who acts and is not merely acted upon, then it must be true that the individual can have a certain kin of ultimate responsibility for how his life goes." Jules Coleman, The Practice of Principle, 60 (Oxford University Press 2001).

${ }^{7}$ John Rawls, Justice as Fairness: A Restatement 18-19 (Erwin Kelly ed., Harvard University Press 2001).

${ }^{8}$ For a useful discussion see G.A. Cohen, The Currency of Egalitarian Justice, 99 Ethics 906, 916 (1989).

${ }^{9}$ See generally Michael J. Zimmerman, Luck and Moral Responsibility, Vol. 97 (Issue 2) Ethics, 374 (1987).
} 
shared world, in terms of rights and duties. In other word, these theories of justice seek not to eliminate the role of luck, but to confine its operation according to their own terms of fairness. ${ }^{10}$

\section{Luck in Distributive Justice}

Egalitarianism is the prominent approach to distributive justice which seeks to reflect the equal moral worth and capacity for responsibility of persons by specifying fair social and economic structures. ${ }^{11}$ The question of fairness in DJ is how to structure the central institutions of society such that people, as moral equals, have substantially similar opportunities to pursue meaningful lives. Interestingly, major distributive justice theorists support the division of labor between private law (as the manifestation of CJ) and tax and transfer laws (as the manifestation of DJ). ${ }^{12}$ An argument for this view seems to be that redistribution through a DJ system is less restrictive of liberty and of our ability to choose a preferred path in life, than is redistribution via regulating bilateral interactions through private law. ${ }^{13}$

The notion of egalitarian fairness in DJ can be gleaned from looking at the types of questions debated among its theorists. First, theorist debate what DJ machine should operate

10 Elizabeth Anderson has presented a compelling critique of formulating egalitarian commitments in terms of luck. Elizabeth Anderson, What is the Point of Equality?, 109 Ethics 287 (1999).

Anderson criticizes what she terms "luck egalitarians" who see the aim of DJ to be exclusively the compensation of undeserved misfortune with the surpluses of undeserved fortune. She criticizes this school for fetishizing the distinction between luck and choice over what she argues are the true aims of egalitarianism-to distinguish between those social relations which enable oppression and exploitation from those that positively ensure democratic equality and equal opportunity for functioning. Anderson claims that both luck and democratic egalitarians are committed to upholding personal responsibility. Luck egalitarians do so by only insuring against certain causes of losses (those due to brute luck), whereas democratic egalitarians do so by insuring against only certain types of losses (guarantees those "capacities necessary to functioning as a free and equal citizen and avoiding oppression" (id at 327). We find many of her critiques of luck egalitarianism compelling. We nonetheless are using luck as our heuristic device to talk about an egalitarian regime for dealing with accidents, because we think it is the most familiar heuristic to motivate notions of fairness. Thus, although our paper is formulated in the register of luck egalitarianism, we think that the substance of our argument could be reformulated in terms acceptable under Anderson's conception of democratic egalitarianism. Our argument in terms of democratic egalitarianism would be that, because interests in the "core", namely to bodily integrity, are so essential to equal functioning, they are exactly the types of losses for which a democratic egalitarian would assure equal compensation, regardless of the source of destruction. We are thankful to Gregory Keating for bringing this point into our attention.

${ }^{11}$ Another prominent approach is welfarism, as laid out by Louis Kaplow and Steve Shavell. See Louis Kaplow and Steve Shavell, Fairness versus Welfare, (Harvard Universiy Press, 2002). While welfarism is, in some sense, an egalitarian theory, it is not driven by an egalitarian impulse, but rather by a welfare maximizing one.

${ }^{12}$ See, e.g., JOHN RAWLS, A THEORY OF JUSTICE 274-80 (1971). See also RONALD DWORKIN, LAW's EMPIRE ch.8 (1986) (arguing that the concern of other people's well-being is the responsibility of the government and not of the citizens in their daily transactions utilizing private property).

${ }^{13}$ For a critique of this sort of liberty-based defense of tax-and-transfer rules as the exclusive domain of redistributive policy, see Anthony T. Kronman, Contract Law and Distributive Justice, 89 YALE L. J. 472 , 473 (1980). 


\section{Accident Law for Egalitarians}

upon; that is, what is the appropriate equalisandum (the thing to equalize)? ${ }^{14}$ Or, as Amartya Sen famously posed the question: "equality of what?"15 The responses from egalitarian theorists include: equality of "welfare,"16 "“primary goods,"17 "resources,"18“"access to advantage,"19 "opportunity for welfare," 20 "capabilities to achieve functioning," 21 and "capabilities for equal citizenship" $^{, 2}$, to name a few.

With few notable exceptions, egalitarians disagree lessabout what should be left out of the DJ machine, than about the best "catchy" term for a single equalisandum that can capture all our widely shared intuitions about how a western egalitarian society should operate ${ }^{23}$ Theorists' views can be seen as an attempt to explore an objective middle ground between purely focusing on people's welfare and purely focusing on their resources, as the relevant equalisandum. Despite these differences, we believe few egalitarian theorists, if any, would disagree that bodily integrity falls within the core of interests that must be collectively insured, that is, inside the DJ machine.

Assuming a given equalisandum, the second thing that liberal egalitarians debate is what limitations should be imposed on its distribution. What would justify a deviation from pure mathematical division of the equalisandum? Many DJ theorists, whether liberal egalitarians or libertarians, seem to agree that other considerations, such as liberty, responsibility, etc., come

\footnotetext{
${ }^{14}$ G.A. Cohen says "an equalisandum claim specifies that which ought to be equalized, what, that is, people should be rendered equal in." G.A. Cohen, On the Currency of Egalitarian Justice, 99 Ethics 906, 908 (1989).

${ }^{15}$ Amartya Sen, Equality of What?, in Equal Freedom: Selected Tanner Lectures on Human Values 307 (Stephen Darwall ed., 1995). The importance of the question, as Sen observes, lies in the fact that, for example, equal opportunities can correspond with very unequal income. Equal income can exist simultaneously with differences in wealth. Equal wealth can co-exist with unequal happiness. Equal happiness can go with divergent fulfillment of needs. And equal fulfillment of needs can be associated with different freedoms of choice. AMARTYA SEN, INEQUALITY REEXAMINED 2 (1992).

${ }^{16}$ John Roemer, Equality of Resources Implies Equality of Welfare, 101 Q. J. ECON. 751 (1986).

${ }^{17}$ RAWLS, supra note 9, at 62, 92.

${ }^{18}$ Ronald Dworkin, What Is Equality? Part I: Equality of Welfare; Part II: Equality of Resources 10 PHIL. \& PUB. AFFAIRS 185, 311 (1981) (resources include mental and physical capacity).

${ }_{19}$ G.A. Cohen, The Currency of Egalitarian Justice, 99 Ethics 906, 916 (1989).

${ }^{20}$ Richard Arneson, Equality and Equality of Opportunity for Welfare, 56 Phil. Studies 77 (1989).

${ }^{21}$ SEN, supra note 18.

${ }^{22}$ Elizabeth Anderson, supra note 10.

${ }^{23}$ See, e.g., John C. Harsanyi, Problems with Act-Utilitarianism and with Malevolent Preferences, in HARE AND CRITICS: ESSAYS ON MORAL THINKING, 89, 96-98 (Douglas Seanor \& N. Fotion eds., 1988); And see also Kenneth Arrow, Some Ordinalist Notes on Rawls' theory of justice, in KenNeth ARrow, COlleCted PAPERS 1, N. 104 (Cambridge Mass, Harvard Univ. Press, 1983.
} 


\section{Accident Law for Egalitarians}

into play in answering this question. ${ }^{24}$ Although there is no consensus on what precise role justice dictates for responsibility, liberty or choice (to use some of the terms that have been employed) in distribution of the equalisandum, there is agreement that these considerations need to play some role. ${ }^{25}$ No matter what equalisandum we endorse, a commitment to liberty and responsibility requires us to make a distinction between differences in resources/primary goods/etc. arising from voluntary, informed choice, and those arising from individuals' differing initial endowments of talent, wealth, opportunities, genes, or un-chosen social and environmental circumstances. ${ }^{26}$ In other words, a distinction should be made between "brute luck" and "option luck", to use Dowrkin's terms. ${ }^{27}$ The idea is to make an objective distinction between luck and responsibility with respect to one's misfortunes. ${ }^{28}$ Bad luck is the individual's problem if it is a result of her choices and ambitions; it is society's problem if it is a result of her un-chosen circumstances. Thus, most egalitarian DJ theorists attempt to design a distributive policy which is "endowment-insensitive" but "ambition-sensitive" which respect both equality and responsibility. ${ }^{29}$

Whether an agent's particular action is a matter of choice, control, or chance (that is, the distinction between brute and option luck) might seem like a metaphysical question which involves a deep analysis of concepts of free will, causation and the like. Yet, in practice it is determined by standards of reasonableness, informed by culturally and temporally specific norms

\footnotetext{
${ }^{24}$ For a short discussion of the way DJ theorists limit equalization of their equalisandum subject to these principles point see Kyle Logue \& Ronen Avraham, Redistributing Optimality: Of Tax Rules, Legal Rules, and Insurance, 56 Tax L. Rev. 157, 161-164.

${ }^{25}$ No theorist really claims that a static snapshot of people's holdings is informative as to whether the society is just. Robert Nozick has distinguished between patterned and historical theories of justice. A patterned theory of justice evaluates holdings at a specific time. A historical theory, in contrast, looks at how the current pattern came about. Nozick argued for a historical theory of distributive justice, libertarianism; our argument in the text is that all theorists are to some extent concerned with the dynamic aspect of holdings, there is always concern for how the holdings came about. Robert Nozick, Anarchy, State and Utopia 161-162 (1972).

${ }^{26}$ See generally WILl KYMLICKA, CONTEMPORARY POLITICAL PHILOSOPHY: AN INTRODUCTION 75 (1990) ("People's fate should depend on their ambitions in the broad sense of goals and projects about life, but should not depend on their natural and social endowments (the circumstances in which they pursue their ambitions).").

${ }^{27}$ See, Dworkin, supra note 5. Our conception of brute luck is somewhat broader than Dworkin's, however. For us, brute luck arises when an individual's misfortune is not the result of a risk she could reasonably have avoided. See Logue and Avraham 161-165 (using the same conception of brute luck to analyze the optimal division of labor between tort law and tax and transfer law.)

${ }^{28}$ When we employ "objective" we mean a standard that is fixed by publicly agreeable notions of reasonableness and representation, as opposed to a "subjective" standard which looks at something about the specific doer, such as intentions, control, etc.

${ }^{29}$ Ronald Dworkin, What Is Equality? Part I: Equality of Welfare; Part II: Equality of Resources 10 PHIL. \& PUB. AfFAIRS 185, 293, 330 (1981); see also G.A. Cohen, The Currency of Egalitarian Justice, 99 Ethics 906, 908 (1989) (arguing that one of the primary egalitarian impulses is to extinguish the influence on distribution of brute luck).
} 
of socially acceptable behavior. Like we stated above, the line between luck and responsibility in DJ is drawn by normative notions of what is fair for members of a political community to expect from one another. To illustrate the role of luck and control in our commonsense assessments of fairness in DJ, consider George who has declined to seek gainful employment and instead enjoys the sands of Santa Monica as a full-time beach bum, and Harriett who was injured during service in the US military. Most would agree that, in 2005 in the United States, there is a fairly strong political consensus that abstaining from work when physically able is not a reasonable choice, and therefore someone who voluntarily decides to be a beach-bum does not have a legitimate demand on the State for income support to satisfy his consumer preferences. Military service, on the other hand has been constructed as reasonable choice, and therefore Veteran health care or income support programs which compensate for resultant injuries are considered legitimate distributive undertakings.

To sum up, distributive justice egalitarians are mostly committed to fairness by creating institutions which allot equal amounts of welfare/opportunity/resource (the equalisandum), but also which reflect notions of responsibility. Responsibility in DJ entails holding people accountable for their choices, therefore immunizing them from misfortunes that either befall them as a function of nature or while making reasonable decisions (brute luck), but not from misfortunes arising from unreasonable choices or informed gambles (option luck). ${ }^{30}$ This is how luck is dealt with in DJ.

\section{Luck in Retributive Justice}

Luck is also an important concept in retributive justice (RJ). Retributive justice requires punishment of a wrongdoer in proportion to the gravity of the wrongdoer's act towards the publicand the victim . Retributive justice focuses on the moral responsibility of the doer and the punishment he deserves. In contrast, CJ focuses on restoring the fair terms of interaction between the doer and the sufferer through the assignment of legal responsibility, but ordinarily without

\footnotetext{
${ }^{30}$ Jules Coleman makes this point well when he says: "In order to realize the idea of responsibility implicated in the concept of a life lived rather than a life had, political institutions must be arranged so that individuals' lives reflect to a greater degree, or to the greatest possible degree, their choices rather than their circumstances of birth and the subsequent influences of fortune." Coleman, supra note 6, at 60-61.
} 
concluding anything about the moral worth of either. The doctrines of tort law compared to criminal law reflect this distinction. ${ }^{31}$

The role of luck in RJ was famously explored byBernard Williams and Tho mas Nagel. ${ }^{32}$ Thomas Nagel, in his seminal paper fittingly titled Moral Luck, brings to our attention the way in which "natural objects of moral assessment are disturbingly subject to luck". ${ }^{33}$ Nagel argued that, in so far as we premise our judgments of moral responsibility on some notion of control-that people can only be held responsible for things reasonably within their control—most of these judgments are suspect. Because outcomes of actions are always, to a greater or lesser extent, consequences of causal forces outside the control of the actor, our moral assessment of an actor is always tainted by the role of forces beyond the actor'scontrol . For Nagel, moral luck complicates the question of how to draw the line between "what is us and what is not, what we do and what happens to us, what is our personality and what is an accidental handicap." ${ }^{\text {"34 Moral }}$ luck raises the question of why equally careless actors should be viewed asmorally different if one party—such as D in our example (the one who hit the pedestrian)—occasions harm whereas another actor — such as $\mathrm{E} t$ (he one who missed her)—does not because of the presence or absence of a victim or a bird, a fact neither party had any control over. This is the moral luck paradox, as presented by Nagel.

The moral luck paradox attracted immediate attention and has persisted as a conundrum for moral philosophers as well as to legal theorists, especially in the area of retributive justice and criminal law. Some philosophers argue that the "successful" driver (D, the one who hit the pedestrian) is more morally blameworthy than the "unsuccessful" driver (E, the one who missed her), because the former caused harm while the latter did not. Yet other philosophers argue that D's and E's moral blameworthiness is identical: unsuccessful drivers are equally blameworthy as their successful counterparts because their failure is attributable to something outside their

\footnotetext{
${ }^{31}$ Gerald Postema explains that "[r]etributive justice concerns the wrong, the wrongdoer's culpability, and the appropriate response of the public. Corrective justice focuses on the victim's loss and the claim to repair for that loss; it is not concerned with punishing, blaming, or exculpating the injurer, or with rectifying the wrong." Gerald J. Postema, Risks, Wrongs, and Responsibility: Coleman's Liberal Theory of Commutative Justice, 103 Yale L.J. 861, 875 (1993).

32 The papers, both entitled "Moral Luck," were originally published in The Aristotelian Society Supplementary, Volume 1, 1976. Revised versions of this paper are included in the excellent anthology edited by Danny Statman. see Statman, D. (Ed.) (1993) Moral Luck. State University of New York Press, Albany, New York, 1-25.

${ }_{33}$ Thomas Nagel, Moral Luck, in Mortal Questions 60 (Cambridge University Press 1979).

${ }^{34}$ Thomas Nagel, Moral Luck, supra note 33.
} 


\section{Accident Law for Egalitarians}

control. ${ }^{35}$ In general though, philosophers have come to a consensus on resolving the moral luck paradox. $^{36}$

Concepts equivalent to option luck and brute luck, more familiar in the DJ context, also play a role in the RJ. Consider Ilay who is a very careful driver who never exceeds the speed limit or violates norms of careful driving. One morning on his way to work he runs over a pedestrian who unexpectedly rushed into the road. Ilay was not blameworthy. In a way, he is outside of the scope of the moral luck paradox. His decision to drive carefully is reasonable, the fact that he killed a pedestrian is something which is beyond his reasonable control, and therefore he is immune from both civil and criminal liability. ${ }^{37}$ With respect to Harriett (who, recall, was injured in military service) and Ilay, RJ theorists and DJ theorists' treatment of luck is similar. If one made a reasonable decision, the luck that strikes is "brute" and is therefore negated. For Harriett the costs of her bad luck, at least to some extent, are negated bysociety in general (through compensation); Ilay's bad luck of killing someone is negated because he is not forced to bear the costs by being held civilly or criminally liable. In both cases, theories of justice (and the law) treat the bad luck as brute luck: it is negated. ${ }^{38}$

The story becomes more complicated once option luck, and not brute luck is involved in brining about the outcome in question. Such is the case with examples D and E presented in the

\footnotetext{
${ }^{35}$ Those who hold this view need to explain why the legal system treats both drivers so differently. This is the legal luck paradox. One of the most powerful responses is that epistemological shortcomings, and nothing else, is what prevents the legal system from imposing a punishment on the unsuccessful doer. The causation of harm signals the legally determinate level of carelessness or criminal intent which is uncertain in the cases of attempt or a victimless reckless act, because we can never know if, in the last instance, the person would not have exercised more care or abandoned the criminal enterprise.(The Model Penal Code imposes, in general, the same punishment for an unsuccessful attempt and the completed crime. Model Penal Code, section 5.05. Yet, it seems that most states don't currently employ this policy.) We find this response problematic because it seems to confuse two distinct stages in the criminal trial. The first is the finding of guilt, to which epistemological shortcoming are relevant. The second is the sentencing to which epistemological shortcomings are irrelevant. In the first stage, paradoxically, the mens rea requirement to find someone guilty of an attempt to murder is sometimes higher than the mens rea requirement for murder. (Check MPP). In the second stage, the stage at which the convicted receives the sentencing "discount" for committing an attempt and not a completed crime, there are no epistemological shortcomings left. The court is presumably convinced beyond any reasonable doubt that the convict would have murdered the target; otherwise the court would not have convicted him in the first stage. Thus, it seems to us that epistemological shortcomings cannot explain the legal paradox.

${ }^{36}$ The literature on the debate is infinite. Some of the recent literature includes, Stephen Morse, Reason, Results, and Criminal Responsibility, 2004 U. Il. L. Rev. 363 (2004); Leo Katz, Why the Successful Assassin is More Wicked Than the Unsuccessful One, 88 Calif L. Rev. 791 (200); David Lewis, The Punishment that Leaves Something to Chance, Philosophy and Public Affairs, Vol 18(1), 63-57 (1989).

${ }^{37}$ We emphasize "reasonable" control because it was in his control in the sense that he could have chosen not to drive at all. But that would be an unreasonable demand of him.

${ }^{38}$ Again, luck is a way of talking about a substantive notion of fairness, of what is appropriate to expect from others, of what constitutes reasonable behavior.
} 
Introduction. Both sped to work; both behaved unreasonably. D had bad luck to hit Amy and E had good luck not to hit anyone. Because their choice of speeding was unreasonable, the upshot of their actions can fairly be termed option luck. Just as George's bad luck in being poor is considered option-luck because it is considered an unreasonable decision to be beach-bum, so are the casual upshots of D's and E's decision to speed considered option luck.

But while DJ theorists agree more or less that option luck should not be negated, RJ theorists are divided on how to deal with option luck. Some argue that both D and E are equally morally blameworthy, while others argue that they are not. This is the moral luck paradox described above. $^{39}$

To sum up, both RJ and DJ theorists seem to agree that bad luck which comes after a reasonable decision is "brute" and should be negated. In contrast, luck which comes after an unreasonable decision is considered "option luck". DJ theorists seem to not negate it, while RJ theorists are conflicted. These insights about the role of luck developed in RJ and DJ sit well with our intuitions about fairness as respecting equality and responsibility. In the next section we claim that these intuitions should be applied to misfortunes traditionally dominated by CJ.

\section{Luck in Corrective Justice}

Corrective justice is concerned with the fair terms of responsibility in bilateral accidents. A doer hits a sufferer. We saw how DJ theorists treat sufferers' luck: brute luck is negated but not option luck. ${ }^{40}$ We also saw how RJ theorists treat doers' luck: brute luck is negated, and there is some debate with respect to option luck. In this section we argue that, althoughthe role of luck in DJ and RJ (determining one's fair share of society's resources in the former instance, and one's moral blameworthinessin the latter ) is different from the role of luck in CJ (determining adequate liability of a wrongdoer and adequate compensation to the victim), there is a lot to be learned from the previous discussion. Specifically, we think that the principles of fairness in luck developed independently for doers and sufferers (in RJ and DJ, respectively) should inform principles of liability and compensation in bilateral accidents.

\footnotetext{
39 Indeed in the literature on moral luck there is some confusion whether both drivers should both to be blamed at the highest level as if they both killed a person, or, at the lowest level as if they both did not, or at some intermediate level. As Zimmerman observed Nagel seems to embrace the idea that both drivers deserve no blame at all. M. Zimmerman, Luck and Moral Responsibility, Ethics 97 (1987), 374 at 382. Zimmerman seems to argue, but he is somewhat vague on this point, that they both deserve the same level of the highest blame. Id 383-4. Zimmerman. ${ }^{40}$ Of course what is debated among DJ theorists is precisely what is properly considered brute, as opposed to option, luck.
} 
Unfortunately, CJ theories have not been concerned with integrating these principles about luck and fairness developed in RJ and DJ in such a way that addresses discrepancies in liability and compensation identified in our initial examples of A-F. This is not to say that CJ theorists are unconcerned with luck. They are, but only with respect to the internal operation of CJ. Indeed, CJ theorists do talk about luck and responsibility as a way of distinguishing those losses for which a specific person is responsible, from those for which no one in particular is responsible, and therefore must lie where they fatefully fall (as a victim's bad luck). Such is the case when a victim suffers injury from a non-negligent doer, and therefore can state no legal claim for compensation. Fairness in $\mathrm{CJ}$ also demands that one will not be able to escape responsibility for behavior which was under one's control and caused harm to another. CJ theorists posit a "luck---control" spectrum which explains which losses are appropriately considered the doer's, and which are the sufferer's, to bear. Losses in which the doer's control was a substantial factor (where the doer did not live up to the objective criteria of reasonable care), are ipso facto not the result of luck, and are therefore the doer's to alleviate. ${ }^{41}$

This is the principle of fairness in CJ. The doctrine of proximate cause in tort law manifests this principle of fairness by negating brute luck for doers. A doer is not responsible for the sufferer's harm even if the doer was negligent, unless the harm was "caused" (proximately caused) by the doer's negligence. One of causation most powerful operations is to shelter the defendant-doer from liability in cases where (bad) luck is the dominant factor which contributed to the plaintiff-sufferer's harm. But why is luck a reason to exempt the doer from liability? It is because the doer did not cause the harm in the sense that the harm was not under his control: it is not fairly considered his responsibility. Finding the doer liable to the sufferer in cases where he lacked control strikes us as unfair. It is unfair, because the doer should not be held responsible for something that was not under his control. ${ }^{42}$

There is much more to be said about the role of luck in the internal operation of tort law. But for our purposes it is suffice to summarize that the instinct about negating brute luck appears

\footnotetext{
${ }^{41}$ Different CJ theorists define these criteria of control differently. Steven Perry talks about control premised on capacity to avoid and foresight, see generally Steven Perry, Responsibility for Outcomes, Risk and the Law, in Philosophy and the Law of Torts 73-123 (Gerald J. Postema ed., 2001); Ripstein, supra note 4, at 94-109 (For a general discussion of the objective criteria of reasonable foresight).

${ }_{42}$ Of course, a tort where everything is under the doer's control does not exist. Luck always plays some role. We are focusing on the cases where luck is the dominant factor which contributes to the harm. Compare In re Polemis \& Furness, Withy \& Co., 3 K.B. 560 with Palsgraf v. Long Island R.R., 248 N.Y. 339 (1928).
} 


\section{Accident Law for Egalitarians}

in the internal operations of CJ, mainly in the doctrine of causation which diminishes the doer's liability in cases where bad luck plays the most significant role. ${ }^{43}$

So in CJ, DJ and RJ, a lot of thinking was sunk into limiting the role of luck, because an active role for luck leaves us uncomfortable. ${ }^{44}$ Unfettered luck is perceived as introducing arbitrariness, contrary to the most fundamental understanding of the operation of justice. In all three theories of justice, it is control (the other side of luck in the spectrum) that we feel should determine outcomes, whether it is the moral worth of the doer and his punishment (RJ), civil liability and compensation (CJ), or her fair share in the social pie (DJ). Negating luck is the way by which RJ, DJ and CJ express their substantive commitment to fairness as respect for equality and responsibility.

So why are we unsatisfied with the negation of luck within each of these forms of justice? We think there are two persistent ways luck continues to operate between the various spheres of justice that undermine the fairness of CJ and current schemes dealing with bilateral accidents. First, the luck of causation gives rise to vastly disparate treatment of equally careless actors (illustrated by cases D and E), and similar treatment of dissimilarly careless actors (illustrated by cases $\mathrm{E}$ and F). Second, the luck of source of misfortune gives rise to unequal treatment of equally blameless victims (illustrated by cases A through $\mathrm{C}$ ). These two ways thatluck continues to operate is why we think that the acoustic separation between forms of justice fails the global "fairness test."

Another way to put these concerns is as follows. What we need is an account of why the luck that is permitted to create the differential outcomes between A-B-C and then D-E, is an acceptable pattern of luck in terms of the first-order moral principles of fairness as equality and responsibility. To be sure, the mere operation of luck alone does not make an outcome unfair or arbitrary. Our claim is that the role luck is allowed to play in sorting cases of misfortune into the CJ versus DJ machines, as well as the role it plays in assigning liability to the unsuccessful negligent actors, is one which undermines the first-order commitments to equality and

\footnotetext{
${ }^{43}$ Even in places where luck plays a secondary role the doctrine of causation is still active. It limits the doer's liability to the extent that she, and not luck, caused the harm.

${ }^{44}$ In retributive justice, luck might determine the moral and legal status of the doer through the role of causation, or at least this is what philosophers have long been debating. But observe the potential opposite role of luck in CJ. In RJ luck is used to assign moral blameworthiness to the "unsuccessful" criminal who attempts a crime but the fortunate intervention of some causal force precludes the fruition of the criminal endeavor. In CJ, in contrast, luck is traditionally used to relieve the driver from responsibility. The doctrine of causation entails that if the sufferer's harm was not caused by the doer's wrongful act but rather by luck, the doer will not be held liable at all.
} 


\section{Accident Law for Egalitarians}

responsibility CJ, DJ and RJ are based upon. We claim that, in so far as theorists are committed to fairness (by negating luck as a way to manifest notions of equality and responsibility) in the global sense-that is, not just equality and responsibility in the circumscribed realm of CJ, DJ or RJ - they must account for the morality of the luck that sorts cases into CJ or DJ or RJ's types of analyses and the patterns of cost bearing it creates.

We are not arguing that $\mathrm{CJ}$ theorists fail to adequately eliminate the unfair operation of luck inside the operations of $\mathbf{C J}$ or that its own terms of fairness are inadequate. Rather, we are saying that there is a principle of fairness which spans the divisions between various forms of justice. We think this global notion of fairness motivates us to formulate principles of distributive, corrective and retributive justice in the first place, and can be understood as a view of people as moral equals with an equal interest in responsibility. ${ }^{45} \mathrm{We}$ feel it is not a useful project to try and conceptualize separate forms of justice that are insulated from each other when to do so violates this global notion of fairness. This is not to say that all forms of justice are reducible to a commensurate currency of fairness, but rather that any principle of justice which respects this global notion of fairness that we would want to choose to guide our approach to accidents will include distributive and retributive notions of fairness.

We now turn to examine in more detail the two ways in which luck plays an unfair role in determining liability and compensation. The following two Sections will develop our claim that the role luck plays, both inside the operation of tort law and in sorting cases into the institution of tort law violates egalitarian notions of fairness; it fails the fairness test.

\section{Luck, Fairness and The Treatment of Equally Careless Actors}

Cases $\mathrm{D}$ and $\mathrm{E}$ demonstrate the role of luck in determining vastly different liabilities for the same careless behavior. We claim that a global commitment to fairness cannot allow such a disparity in the assignment of liability to these two actors. We do not argue that doers such as D and $\mathrm{E}$ are morally indistinguishable, and therefore must be necessarily treated identically. We are

\footnotetext{
${ }^{45}$ A formalist approach to CJ, such as that of Ernest Weinrib or Peter Benson, would of course reject the idea that there can be a principle of fairness at once external to $\mathrm{CJ}$, which can therefore be employed to evaluate it, and internal to it as the standard of fairness articulated by its own normative structures. (We thank Ernest Weinrib in personal communication for this point). This objection however begs the premise of our initial argument, which is that there is a fundamental notion of fairness - that of treating people as equals and as having an interest in responsibility - which can and should inform justice in transactions (CJ) as well as justice in other contexts (such as in distribution). We do not argue that this broad, global notion of fairness gives us the contours of justice in all contexts, but merely that the operation of any form of justice - internally and considered in conjunction with other forms of justice-must at very least be fair according to those global terms.
} 


\section{Accident Law for Egalitarians}

not assessing the morality of the doers but the wrongfulness of their conduct. Rather, we claim that all careless action-irrespective of the causation of harm-is an appropriate object of concern for any principle of justice in transactions because all such action objectively disrespects the security interests of others by imposing unreasonable risks on them in pursuit of one's own ends. Relying on causation of harm as a necessary determinate of liability is unfair because causation is primarily a function of luck.

We now explain this in more detail. There are two primary ways in which luck conditions the liability of similarly careless actors. First, there is the familiar issue of causation luck. Christopher Schroeder illustrates well the wrench moral luck - through the doctrine of causation-throws into CJ's project of grounding tort law in some sense of moral responsibility. He reminds us that moral theories, in so far as they serve as guides to action ${ }^{46}$, usually concern themselves with the ex ante viewpoint, both judging actors and choices from the viewpoint of what they knew or should have known at the time of action. ${ }^{47}$ In this sense tort law is out of sync with most moral theories of responsibility because its cause-in-fact requirement employs an ex post viewpoint to make a moral assessment. The cause-in-fact requirement of tort law premises liability not on negligent action, but on the ex post "contingency of what causal chain actually materializes after [one] acts." ${ }^{48}$ Schroeder argues that the conclusions of corrective justice-that the 'successful' negligent driver should be assessed full liability and 'unsuccessful' negligent drivers zero liability — are therefore morally arbitrary.

In the liability lottery, luck is not limited to the role of causation: the level of liability for which an actor might ultimately be held responsible also involves the lottery of victims. Hitting a victim with a frail, "eggshell” constitution or with high wages, will necessarily result in higher compensatory damages than similar impact with a more stalwartly constituted or low-income victim. Thus, the objective probability of causing a particular type of injury by a specific careless act may be equivalent between two similarly careless actors, but the expected harm from such an activity — the probability of injury times the magnitude of harm entailed in such an injury-

\footnotetext{
${ }^{46}$ Coleman makes a similar point about liberal political philosophy being directed at guiding action by providing criteria for judging between choices, saying "the fact that events affect individual welfare or well-being is normatively important because effects on individual welfare are the kinds of things that provide agents with reasons for acting." Jules Coleman, The Practice of Corrective Justice, in Philosophical Foundations of Tort Law 53-71,54 (David G. Owen ed., 1995).

${ }^{47}$ Christopher Schroeder, Corrective Justice and Liability for Increasing Risks, 37 UCLA L. Rev. 440 (1990).

${ }^{48} I d$., at 457.
} 


\section{Accident Law for Egalitarians}

might not be equal. We might term this second operation of luck — the luck of hitting a particularly frail victim— "eggshell luck". 49

Before we suggest our own two pennies on the causation lottery and the eggshell lottery, let us first explore how CJ theorists traditionally deal with moral-luck-like critiques.

A common response to the apparent unfairness of luck's role in manifesting massively different liability for similarly careless acts refocuses the question as one of ex ante as opposed ex post fairness. Such an argument defends the current practice of relying on causation luck to determine liability for carelessness by casting the practice as one which exposes equally careless drivers to equal riskof liability. This argument casts th e causation lottery as fair from the ex-ante perspective, although it does not assure equal treatment from the ex post perspective. Therefore, if a careless driver's actions expose other drivers around him to a $40 \%$ chance of injury, he himself is exposed to a $40 \%$ chance of financial liability for such injuries. Jeremy Waldron describes such an argument as a "liability lottery" in which causation does not necessarily have independent normative relevance in grounding the duty to compensate, but merely "happens to be the method we have adopted for ensuring that those who expose others to risks are exposed to substantially the same risk themselves." ${ }^{\circ 0}$ It is easy to imagine how the ex ante fairness argument could just roll eggshell luck into causation luck: the lttery of liability is ex ante fair with respect to both kinds of luck because similarly careless drivers are being subjected to the exact same risk of damages as that to which they expose others. The existence of eggshell victims is an empirical fact that is already factored into the calculus of the liability lottery. The ex-ante perspective led Schroeder to advance a scheme of accident law where both careless drivers - the successful and the unsuccessful ones -- would be assessed equal monetary liability, which should be set at the level of expected harm of the negligent activity. ${ }^{51}$

We would like to make two points about the arguments describing the liability lottery as ex ante fair. First, although such an account might resolve some discomfort about the fairness of the comparative treatment of similarly careless drivers, it leaves untouched the question of the

\footnotetext{
${ }^{49}$ We are thankful to Charles Taylor for raising questions about this other level of luck.

${ }^{50}$ Jeremy Waldron, Moments of Carelessness and Massive Loss, in Philosophical Foundations of Tort Law 387-408, 407 (David G. Owen ed., 1995).

${ }^{51}$ Schroeder, supra note 47, at 472. Schroeder distinguishes his proposal from 'communal or group responsibility' because "the ex ante proposals advanced here are predicated on individual, private morality, arguing only that implementation can be done in nontraditional litigation structures" to conform more closely with moral notions of accountability and eliminate the "lottery" character of liability based on outcomes as opposed to faulty actions.
} 
absolute appropriateness of our current practice of assessing either full (when causation strikes) or zero (when careless action luckily eludes victims) liability. ${ }^{52}$ This question is especially salient in cases where eggshell luck is at work-or, to borrow Jeremy Waldon's terms-where "moments of carelessness" cause massive damages. Therefore, causation and eggshell luck give us occasion to question the motivation for limiting ourselves to accident schemes in which the only possibilities are zero liability or full liability.

Secondly, assume we are satisfied that any claim of unfair treatment by a successful careless driver (who is made to pay full liability) in relation to an unsuccessful careless driver (who pays nothing), is resolved by reference to the ex ante identity of the liability lottery faced by careless drivers to the risk lottery faced by their potential victims. This does not satisfy us with respect to the claims of unfair treatment by careful drivers in relation to unsuccessful careless drivers. From the point of view of careful drivers, such as our case F (who consistently drives carefully and has occasioned no harm to others), it may be fair to hold successful careless drivers liable for full damages, yet unfair to allow unsuccessful careless drivers (such as E who consistently drives carelessly and also occasions no harm) to be treated identically to careful drivers, escaping any fine or liability. We argue that the foundational values of CJ should lead us to be unsatisfied with relying exclusively on causation to audit careless action because it underenforces the norms of responsible action which respects others' security interests as equally important as one's own.

Another version of this ex ante fairness argument as a justification for the current regime is framed in terms of a single, reoccurring actor engaging in careless activity, as opposed to comparing two different similarly situated careless actors. Tony Honore offers such an account for why charging the "successful" driver but not the "unsuccessful" driver is not unfair. ${ }^{53}$ Rather than comparing two different drivers, he asks us to think of these two drivers as two different versions of our own selves. In the long run, the current tort system is a fair lottery, Honore argues, because most of the time my 'unsuccessful driver self' is not found liable and therefore

\footnotetext{
${ }^{52}$ Jeremy Waldron makes this point from the perspective of moral desert of careless actors. He says that although the liability lottery may be "macabrely appropriate", it is not necessary that we achieve compensation of victims by a system that imposes a liability lottery where the outcomes are either substantial liability or zero. He claims that if we can find better ways of compensating victims then, "imposing this risk on negligent persons will seem unnecessarily retributive and arbitrary, in the sense of being insufficiently motivated by any good reason." Waldron, supra note 50, at 406 .

${ }^{53}$ Tony Honore, Responsibility and Luck: The moral Issues of Strict Liability, 104 law Quarterly Review 530 (1988).
} 


\section{Accident Law for Egalitarians}

does not pay for her behavior. Whenever my "successful careless driver self" is found liable, and therefore is required to pay damages, it is just the debit side of a long run credit accumulated in the multiple-selves personal account. Since the credit and debit tend to even out in the long run, it is not unfair to charge the successful and the unsuccessful driver differently. We disagree for several reasons.

First, as Ripstein noted, to assume that the credit and the debit parts in each person's life will always cancel out is a very optimistic empirical assumption. It assumes a perfect correlation between harm creation and risk creation. The more harm a driver causes (and therefore is required to pay more damages) the more we need to assume that he must have escaped liability for risk creation; otherwise the credits and the debits will not cancel out. Harm creation and risk creation may be correlated, but not necessarily perfectly so. For example, two doers can impose the same risk but due to pure eggshell luck, one creates more harm than the other. It is exactly this luck with which we are concerned that Honore's argument leaves unsettled. Moreover, (and again as an empirical matter) as Risptein observed, if someone starts by compensating another, she may never get the chance to impose risks on others. ${ }^{54}$ Second, it is hard to reconcile Honore's claim that both driver are treated fairly with the fact that F, as the consistently careful driver, would definitely have a claim in justice against being treated identically to $\mathrm{E}$ who consistently drivers recklessly but always escapes liability on account of luck alone. Third, and more importantly, even if Honore is correct empirically, and even if his system is fair (in the long run) it may still be the case that one can think of a system which is, also in the long run, even more fair because it is not only fair from the ex-ante perspective, but also from the ex-post perspective. This is what we try to do.

Another familiar way CJ theorists address this apparent unfairness of unequal treatment of equally careless actors is by reminding us that corrective justice is not concerned with the assessing the moral status of negligent actors, but rather with fairly assigning responsibility to the consequences of the careless actions. For example, Coleman argues that CJ deals with "objective" wrongdoings which do not necessarily "mark a moral defect in the agent," and therefore, the duty to repair wrongful losses is not because the injurer is wrong, but rather

\footnotetext{
${ }^{54}$ Risptein, supra note 4 , at 74.
} 


\section{Accident Law for Egalitarians}

because the wrongful loss is the doer's responsibility, "the result of his agency". ${ }^{55}$ Ripstein agrees that liability must be assigned in accordance with morally acceptable norms of responsibility, but rejects the idea that "lack of care should be the relevant dimension along which similarly situated people [should be] treated alike." ${ }^{, 56}$ For Risptein, "[t]he failure to exercise appropriate care is one moral failing among others", and it is not clear what the rationale is for classifying people as relevantly similar along that dimension compared to other possible moral failings. ${ }^{57}$ Again, because $\mathrm{CJ}$ is making an objective inquiry into the wrongness of an action, not an actor, the fact that others are equally blameworthy in a moral sense is not relevant. Ripstein explains that, negligence is not a sign of moral defect, but rather "a failure of conduct", and CJ does not set out to "ensure like treatment of all bad behavior", but rather to assign the costs of negligent accidents fairly. ${ }^{58}$

If we grant that $\mathrm{CJ}$ is not concerned with the moral evaluation of actors, and rather concerned with assigning liability on the basis of objectively faulty actions, does the moral luck critique still offer us anything? We think the answer is yes.

We will make three points to support this claim. First, with respect to the faulty action versus faulty actor distinction made by various CJ theorists, we think this is an important distinction which, we in fact endorse. However we believe it can be applied more coherently than $\mathrm{CJ}$ theorists do in defending the current tort law system. We are not proposing that D and $\mathrm{E}$ should be treated exactly alike because they are moral equals, but rather that their similar defect of conduct - their similar wrong in disrespecting the security interest of others-should trigger a similar concern, though not necessarily an identical remedial response. In fact, we are, just like CJ theorists, not fixating on the doers' moral worth. We also care about the faulty action and not the faulty actor, only we do not condition our inquiry on the misfortune of harm.

The operation of luck illustrated by our examples D and E demonstrates that sorting cases into the $\mathrm{CJ}$ machine happens in such a way that is under-inclusive of egalitarian foundational commitments to negating luck to manifest equality and responsibility. Indeed, there are others

\footnotetext{
${ }^{55}$ Jules Coleman, Risks and Wrongs 324-326 (1992). Coleman points out that retributive justice is concerned with annulling the consequences of wrongdoing on the basis of the moral blameworthiness (culpability) of wrongdoers. CJ, unlike retributive justice, does not asses the wrongness of the doer, but rather of the action, according to an objective standard of fault to determine liability. [hereinafter Coleman, Risks].

${ }^{56}$ Risptein, supra note 8 , at 74.

${ }^{57} \mathrm{Id}$., at 81 .

${ }^{58} I d$., at $74,80-82$.
} 


\section{Accident Law for Egalitarians}

who manifest this same defect of conduct, namely unsuccessful careless actors, who escape any consequences for their action. The principle of equal respect to others' liberty and security interests, embodied in the standards of care of tort law, can be used to evaluate all action, including action which does not cause harm. As Schroeder points out, describing some action as faulty presupposed a "hypothetical imperative"; in CJ such an imperative might say that "if you want to treat others as equals, you must exercise appropriate care in your interactions with others" and action is faulty when it does not comport with this imperative. He points out therefore that 'faulty' can "identif[y] an aspect of actions that can be present regardless of whether harm is caused in any specific instance." 59 To use his example, faulty free-throw form can still be described as 'faulty' even if it makes $25 \%$ of the shoots. Indeed, in order to use objective wrongdoing (fault) to morally ground the duty to hold D liable but absolve E of any costs, it must mean something more than just a "redescription of the fact that the action has caused harm." 60

Our second point is that we think that to use faulty action to ground the duty to compensate implies that we should be concerned with all such faulty action, even if it luckily does not cause harm. The normative role of faulty action in justifying the duty to compensate implies a concern about such action-because it does not show respect for the interests of others as equal to one's own interests - that must be somewhat independent of the fact harm is caused in some instances. Most CJ theorists defend the fault principle over strict liability precisely because they do not see the occasion of harm as a causal upshot of agency as morally sufficient to ground the duty to compensate. Drawing from the literature on moral luck, we think that the existence of harm may solve an epistemological problem we may have (but may not necessarily have) in detecting faulty behavior. Harm, in other words, is a sufficient, but is not a necessary, starting point for our inquiry about the doer's behavior. This is not to say that all similarly faulty action ever can be treated identically, merely that our inquiry into fair treatment of careless actors should not be limited to the cases where harm manifests.

Of course the fact that harm did occur is relevant to CJ. Corrective justice theorists would respond to our discomfort about the unequal treatment of $\mathrm{D}$ and $\mathrm{E}$, despite their relevant similarity, by reminding us that, in the case of $E$ there was no victim. The now near consensus on

\footnotetext{
${ }^{59}$ Christopher H. Schroeder, Causation, Compensation, and Moral Responsibility, in Philosophical Foundations of Tort Law 347-362, 353 (David G. Owen ed., 1995).

${ }^{60} I d$., at 354 .
} 
the centrality of correlativity in CJ shows that the existence of a victim is not merely an occasion to evaluate a doer's action, but a fundamental component of the inquiry into the principle of justice. If there is no mess to clean up, there is no occasion to ask the question of CJ: who should bear the costs of this misfortune? As Weinrib puts it, "tort law is not concerned solely with the defendant's emission of a harmful possibility but with that possibility's coming to rest on a particular plaintiff." ${ }^{61}$ Therefore causation does not as much particularize the defendant as a uniquely blameworthy doer, as it particularizes the plaintiff as the appropriate recipient of compensation for the losses attributable to the wrongdoer's carelessness. Rectification of wrongful losses therefore restores the initial equality between the plaintiff and defendant.

Although the operation of $\mathrm{CJ}$ rectifies the wrong between that specific doer and sufferer, we claim that the wrongful "emission of a harmful possibility" by the unsuccessful actor is still an outstanding matter of social concern. The response of CJ to concern over the comparative treatment of $\mathrm{D}$ and $\mathrm{E}$ does not so much justify the unequal treatment, as much as it begs the question of the sufficiency of the limited question posed by CJ to this situation. That is, the fact that we do nothing with E but assess D's liability is the result of the theoretical and institutional segregation of CJ and RJ, not because there are not relevant questions to ask in the case of E, questions that are motivated by the same concern for equality and responsibility as the CJ question.

This is not to say that the normative criteria of fault in corrective justice should or can be collapsed into the criteria of moral blameworthiness in retributive justice. Rather, retributive principles may constrain and inform our actions in the traditional CJ realm. Various theorists have argued thatretributive principles should constrain the operation of CJ in several respects. For example, Tony Honore and Jeremy Waldon have both explored how the retributive principle, which forbid imposing sanctions massively out of proportion to the gravity of an offense, might demand some sort of loss spreading mechanism (such as insurance), and abandonment of "zero or full" liability schemes. ${ }^{62}$ Moreover, The retributive principle which require imposing sanctions in proportion to blameworthiness may also inform our actions in the traditional CJ realm because all careless action, whether or not it manifests in harm, disrespect the security

\footnotetext{
${ }^{61}$ Ernest Weinrib, Causation and Wrongdoing, 63 Chi.-Kent L. Rev. 407, 414 (1987).

${ }^{62}$ Tony Honore, Responsibility and Fault 87 (1999); J. Waldron, supra note 50.
} 


\section{Accident Law for Egalitarians}

interests of others and therefore is of some social concern. ${ }^{63}$ While consideration of retributive principles will not give us a precise formula for the liability we should impose on careless behavior, they do point our consideration to actors such as E, who escape liability because he caused injuries to no specific victim, but who nonetheless flaunt social norms of careful conduct putting others at risks, and generate very real general social costs.

The reasons why cases $\mathrm{D}$ and $\mathrm{E}$ are not problems for $\mathrm{CJ}$ are internal to $\mathrm{CJ}$, and demonstrate that global considerations of luck do not pose a problem for the coherency of the theory. We agree that many $\mathrm{CJ}$ theorists offer resolutions of moral-luck-likeobjections about disparities in liability that are internally coherent to CJ. We just believe internal coherency is not sufficient in the face of patent unfairness that results from segregated, even if internally coherent, spheres of justice. We claim that CJ theorist cannot stop with giving a coherent account internal to their own theory, they must deal with the global problem of fairness that is created by maintaining a distinction between $\mathrm{CJ}$ and RJ if they simultaneously hold commitments to global fairness. Therefore, in sum, our second point is that to focus on harm as the exclusive trigger for liability belies maintaining that the CJ-RJ distinction is valued over, what in our view should be, a lexically prior commitment to global fairness.

Our third point(which is logically distinct from the previous points)for why all careless conduct should be an object of social/normative concerns is that the unsuccessful negligent driver does actually occasion harm to society. This social harmis ignored under CJ. By behavi ng without care, D has violated the norm of responsibility, the foundational value of CJ which demands we all show equal regard and respect for the interests of others, and by doing so he has imposed costs on others in his sphere of action. Except in interional torts , in most accidents the identity of the victim is determined by a lottery. Actors such as our example D (who consistently drives carelessly) does interfere with many other people's plans, he does impose costs on other people in terms of their liberty. Other drivers, like F (who consistently drive carefully.), need to change their behavior by showing extra care and caution on the road as D menaces their security interests with his car. It seems that once we are committed to the standard of care as a manifestation of a specific responsibility to show concern for the others' security interest in a given realm, it is arbitrary to restrict consequences to only those who are unlucky enough to

\footnotetext{
${ }^{63}$ Honore makes the distinction between two aspects of retributive justice, "[o]ne requires that a sanction be imposed that is roughly proportionate to the moral gravity the conduct" and the other "forbids that a sanction be imposed that is out of proportion to the gravity of the conduct." supra note 62, at 83 .
} 
cause harm. We think that the fact that unsuccessful negligent actors have violated the norms of equal terms of interaction, in conjunction with the fact that this forces others to compensate for their disregard, would lead those committed to a global notion of fairness (understood as commitment to equality and responsibility by negating brute luck) to think such actors should be assessed at least some level of liability for their actions (although not necessarily the same level of liability as a successful actor). ${ }^{64}$

The proceeding discussion was dedicated to interrogating the moral acceptability of the role of luck in liability. So far our comments have focused on critiquing the role luck is permitted to play in tort law as both intuitively unfair in several respects, and as contrary to the foundational commitments of corrective justice to equality and responsibility. Causation luck and eggshell luck make us question the fairness and appropriateness of a system where similarly careless actors are either subject to full (and often massive) liability, or zero liability, depending on something outside of their control—-the placement of a victim and/or the physical characteristics of that victim. We believe the relying exclusively on causation to audit careless action under-enforces the very foundational values of CJ and belies a theoretical weakness of CJ, an unnecessary concern with maintaining an acoustic separation from related principles of justice, namely RJ. We have argued that CJ posits careless action as a normative concern, independent of its ripening into harm to another, and that notions of desert, traditionally relegated to the RJ realm, do enter into our commonsense judgments about how we should design a scheme which both compensates accident victims and holds those who create risks and harms accountable.

As a normative matter, luck alone cannot give us the contours of proper practice. As in current tort doctrine, liability is not determined by the physics of causality, but ratherby settled notions of what we duties of care owe each other, and when we think cetain risks are reasonably within the foresight and control of actors. In the last section we will develop these points further, but for now we would like to suggest that our discussion of luck would lead us to conclude that any acceptable scheme of accident law inside an acceptable "zone of fairness" would (1) involve some assessment of liability to unsuccessful careless actors and (2) consider assessing less than full damages to those successful careless actors whose level of carelessness is massively out of

\footnotetext{
${ }^{64}$ The acceptable levels of liability of successful versus unsuccessful wrongdoers is take up in further detail in the Conclusion.
} 
proportion to the harm ultimately caused because of the 'eggshell' characteristics of their victims. Several schemes, including the one advanced by Schroeder where all similarly careless actors are charged expected harm, or a mixed scheme where successful careless drivers are charged close to full damages and unsuccessful are charged expected harm, would fall in the "zone of fairness". We are not proposing constructing a perfect scheme in which all luck is negated, assuming it would even be possible to do so. To make such a proposal begs the initial question, which is not whether luck has played $a$ role in determining an outcome, but rather whether luck has played a morally acceptable role. Fairness, like reasonableness in the law, is a zone whose boundaries are set by foundational commitments to substantive notions of equality and responsibility.

We now turn to the other area where, in our view, luck is allowed to play a morally unacceptable role in the current tort regime.

\section{Luck, Fairness and The Treatment of Equally Blameless Victims}

Symmetric to the CJ - RJ divide we discussed above, there is a CJ - DJ divide which allows a morally unacceptable role for luck in determining treatment of equals on the side of victims. Although the unequal treatment of equally innocent victims has been given less attention in the literature, it poses an equally significant problem as that of equally negligent actors for CJ theorists who are also committed to a global notion of fairness. ${ }^{65}$ Consider again the cases of A, $\mathrm{B}$ and C's misfortune. In each of these cases the compensation available to the victim is entirely a function of luck. That is, in none of the examples was the victim to blame for his or her misfortune; they are similar cases in that they are all blameless victims of some exogenous force. Only luck, brute luck, determines whether the harm was caused by an agent or by nature, and only brute luck determines the level of insurance carried by their respective tortfeasor. But while the attempt to nullify the role of brute luck in the unfortunate vicissitudes of life is a major issue in the DJ literature and the political institutions proposed therein, there is no similar concern in the CJ literature. (As we saw above, CJ is occupied with negating luck, but only to internally immune doers from liability). Paradoxically, major political theorists support the division of labor between $\mathrm{CJ}$ and DJ, thus ignoring the crucial role that luck plays sorting people into the CJ

\footnotetext{
${ }^{65}$ Some authors have addressed these concerns. See generally Marc A. Franklin, Replacing the Negligence Lottery: Compensation and Selective Reimbursement, 53 VA. L. REV. 774, 808-14 ( 1967 ); Stephen D. Sugarman, Doing Away with Tort Law, 73 Cal. L. Rev. 555 (1985); Schroeder, supra note 59.
} 


\section{Accident Law for Egalitarians}

or DJ machine in the first place. We claim that lack of control for victims is a relevant vector of similarity to the lack of control for defendants (which the CJ machine does recognize). There is no principled reason to make a distinction between the compensation due equally blameless victims on the basis of the cause of that loss. Therefore, it offends justice that they have so vastly distinct prospects for compensation. ${ }^{66}$

Our concern in this paper is with equal compensation for injuries to bodily integrity, an object of normative concern in RJ, DJ and CJ alike. If CJ theorists are committed to protecting the specific interests protected by the standards of care in tort doctrines, then there seem to be no a-priori principled reason to distinguish between the sources of destruction of these interests in assuring innocent victims recourse to compensation. ${ }^{67}$ We argue that all persons who suffer the destruction of an interest in bodily integrity should be equally compensated, regardless of their ability to ascribe such loss to another human agent. This relevant similarity of equally blameless victims is necessitated by the first-order commitments of egalitarianism, that persons should have equal opportunity to pursue a meaningful life and to be responsibility for the outcomes of their life, in combination with our substantive argument that source of one's injury is not a morally acceptable role for luck to play. Of course, the question of which kinds of losses should be compensated is not obvious from this approach. As we mentioned above, what sorts of interests are essential to allow people equal opportunity to lead a meaningful life is a normative

\footnotetext{
${ }^{66}$ Some might argue that victim of a tort and the victim of nature or a disease are in fact not equally situated, even if they both lost their sight due to no fault of their own. This point goes only to resolving the apparent unfairness of unequal treatment of similarly injured victims of nature versus agents; it does not address the unfairness of differential compensation to blameless victims because the their "injurer luck" (whether the agent was legally fault or not, whether the injurer's fault was a proximate cause of the victim's harm, whether the injurer carried insurance or not, whether he ran away from the accident scene or not, etc.).

We do not think it is in any way obvious that being injured by an agent is indeed worse than being injured by nature. Putting the contemporary differential compensation schemes aside, one might "prefer" the death by a drunk driver because that might give her a sense of control in her remaining life. On the other hand, there might be something uniquely devastating about losing a loved one to forces outside the bounds of our mortal comprehension or control.

The only compelling argument that agent-created misfortune might be worse than "natural" misfortune would be that the former involves some type of dignitary harm to the victim. If one believes that Amy, the victim of an agent's carelessness, is indeed worse off than Carol, the victim of a cruel god, on these grounds and therefore deserves more compensation, any justice system could incorporate additional compensation for such a dignitary harm should it prove legitimate.

${ }^{67}$ Surprisingly, even Schroeder who did propose pooling negligent risk creators together, maintains the distinction between CJ and DJ. Schroeder concedes that his scheme of risk-pooling, which he believes complies with CJ, is arbitrary in that it does not compensate for injuries that are not the result of negligence. He then suggests that such arbitrariness is not the concern of CJ but of DJ. Christopher Schroeder, Corrective Justice, Liability for Risks, and Tort Law, supra note 47, at 159. We in contrast are worried by this arbitrariness and cannot find our condolences by maintaining the CJ-DJ distinction.
} 
question, one which DJ theorist have debated at length, and on which we offer no particular view in this paper.

Again, some CJ theorists do not justify or even defend this unequal treatment of innocent victims. Rather, they point to division of labor between CJ and DJ and claim that cases such as A-C, on account of the source of misfortune, simply sort themselves out into different schemas of justice. This is not a justification of the disparate treatment as much as it is a description of it. As in the question of unequal treatment of equally negligent actors, it begs the question of why we start from the position of an a priori commitment to a division of labor between CJ and DJ if it comes at the price of generating such inequalities? If corrective justice is fair and treats people as equals, it must do so not only internally, but also in terms of how people get into the CJ system in the first place. Yet, most theorists have claimed that the internal rules of corrective justice take care of this: that the rules for deciding if something qualifies as faulty action or a wrongful loss and therefore deserves to be sorted to the CJ machine, do not pose a problem for fairness.

Recently, some theorists have relaxed the restriction of distributive considerations in CJ. Various theorists assert that the normative strength of CJ claims is influenced by the fairness of the underlying holdings CJ protects from wrongful transfer. ${ }^{68}$ In this view, the CJ machine stalls only when the underlying distributive shares are disturbingly distant from the demands of distributive justice. They would refuse Marie Antoinette's claim for her tortiously trampled torte, but might not refuse much beyond that.

However, we are claiming something more, that the actual rules for distinguishing between what is in the sphere of corrective versus distributive justice, as they currently function in our tort system, produce outcomes incompatible with an egalitarian commitment to fairness. Most CJ theorists hold that $\mathrm{CJ}$ is a distinct, independent system, and that there are reasons it should remain so. ${ }^{69}$ We not turn to exploring some of the reasons that have been offered in defense of this proposition.

How and Why are Corrective and Distributive Justice Distinct?

\footnotetext{
${ }^{68}$ Coleman, Risks, Risks, supra note 55, at 350-354; see also Ripstein, supra note 4, 264-296.

${ }^{69}$ Indeed, Coleman famously abandoned his annulment thesis because it failed to differentiate corrective form distributive justice. Coleman, Risks, supra note 55, 311-312.
} 


\section{Accident Law for Egalitarians}

Recall our argument that there is no fundamental concept or value upon which we can justify the normative necessity of a distinction between CJ and DJ. That is not to say that the distinction cannot be analytically made, but rather that it must be evaluated and justified in the same way any human construct is evaluated-with reference to values we share. ${ }^{70}$ The real question is therefore why we would want to maintain such a distinction. Although we will direct most of our comments in the following sections to the debate around how and why CJ is distinct from DJ (mainly because there has been a significant literature on this distinction), may of our arguments are meant generally to be about why $\mathrm{CJ}$ is a distinct and insulated principle of justice, from either DJ or RJ.

\section{Harms by Agents vs. Harms by Nature}

One common way in which corrective justice theorist justify the division of labor between CJ and DJ is with reference to the sphere of human action upon which they operate. Many theorists have characterized CJ as operating on agent-created misfortune, while DJ operates on those misfortunes brought about by acts of nature or by the normal, acceptable operation of political, economic or social institutions. ${ }^{71}$ This distinction is 'true' in a tautological sense that we now describe the subject of tort law as a non nature-human occasioned harm. But even where nature had a primary role in causing harm-for example in the case of the hurricane Katrina-there are always ways to describe the harm in such a way that an act or omission of a human agent also contributed to it, say bynot allocating sufficient resources to strengthen the levees of a nearby lake. Thus, where we draw the line between acts of man and acts of God determines, and is not determined by, the boundaries of tort law as we know it. And this decision-where to draw the line-should pass the fairness test, or at least so we argue.

Moreover, even where a harm was clearly caused by an agent, the misfortune is not necessarily sorted into the CJ machine. Consider two examples. Various institutions of

\footnotetext{
${ }^{70}$ We thus reject Weintrib's internal, circular, justification for corrective justice. Weinrib's formulation seems to rest on the normative grounds of coherence as the egalitarian manifestation of justice. But if coherence leads to not treating people as equals, as we argue, then local coherence loses its normative force. There is no reason to think that Weinrib is indifferent to the fact that $\mathrm{CJ}$ is costly in terms of global equality. But, as Weinrib is not involved in designing an optimal tort regime, but rather in describing what a tort system is all he could agree to is abolish tort law altogether and implement a different system, which will not be called tort law. We are not committed to calling the system we propose below tort law, so we hope Weinrib will join us.

${ }^{71}$ Stephen Perry, On the Relationship between Corrective and Distributive Justice, in Oxford Essays in Jurisprudence, 4th series 238 (Jeremy Horder, ed., Oxford University Press, 2000); Coleman, The Practice of Corrective Justice, supra note 46 at 66; Weinrib. Aristotle ("The law treats them as equals if one commits and the other suffers injustice"). Aristotle, Nicomachean Ethics at V4, 1132a5.
} 


\section{Accident Law for Egalitarians}

distributive justice also operate on misfortunes occasioned by human conduct. GM shuts down operations in Flint Michigan, a very specific act of human agency, and thousands of devastated workers seek compensation for various institutions of DJ: unemployment, food stamps, job training, etc. In this case the condition of human agency and causality is satisfied. Or, to take a more recent example, when hurricane Katrina hitthe southern coast of the U.S and hundreds of thousands were economically harmed (ignoring the thousands of tragic deaths for a second) we usually do no think that all those victims have a right to compensation from anyone in particular At best, we think they might have a sound plea for charity, even if a major reason for their loss is that resources to strengthen the levees of a nearby lake were negligentlyshifted, by humans, to a different place.

Second, tort law (the institutional manifestation CJ) does not fully take care of one's losses even once it recognizes the course of events as providing grounds for a legitimate claim. If, after you are laid off by GM you express your frustration by punching the GM CEO, he will be able to recover parts of his losses, but not those considered as pure economic losses. ${ }^{72}$

The reasons neither of these misfortunes is sorted into institutions of CJ are not because of the feature of human agency, but rather because of some formal rule internal to corrective justice: that of duties and correlative rights. Put differently, the reason this misfortune is not sorted in the CJ machine, has to do with the structure of CJ. Because welfare is not a correlative concept, then, at least under Weinrib's formulation, the sufferer (the fired GM employee and victims of Katrina) has no exclusive right to her specific level of welfare, she has no right for a specific stream of income, and therefore the doer has no correlative duty to protect it. ${ }^{73}$

Therefore, it is not some fundamental concept of human agency which gives boundaries to CJ; rather the boundaries are determined by the form of rights internal to CJ which underlie the victim's claim.

\footnotetext{
${ }^{72}$ See Restatement (Third) of Torts: Prod. Liab. § 21 (1998)

73 "In the law's contemplation, the increase in welfare through having a right and the decrease through the infringement of a right are the consequences rather than the grounds of the right. That is why (as in cases of negligently caused economic loss) a decrease in welfare that does not violate the plaintiff's rights is not actionable" Ernest Weinrib, Correlativity, Personality, and the Emerging Consensus on Corrective Justice, 2 Theoretical Inquiries L. 107, 120 (2001) (footnote omitted) [hereinafter Weinrib, Emerging Consensus]. A similar reason provided by Benson has to do with the difference between nonfeasance and misfeasance. Benson argues that the exclusion of compensation for economic loss rests on the old principle that there is no liability for nonfeasance. Peter Benson, The Basis for Excluding Liability for Economic Loss in Tort Law, in Philosophical Foundations of Tort Law 427, 457 (Owen ed, 1995). This principle, Benson argues, articulates an idea of responsibility towards others: "individuals must only not injure what already belongs to others; protected interests are defined in terms of what others have (suum), not what they need or want".
} 
The nature of $\mathrm{CJ}$ as a distinctive principle of justice operating on the realm of human occasioned harm is also expressed in Coleman's concept of responsible agency and Perry's concept of outcome-responsibility. Coleman's concept of responsible agency is the principle of $\mathrm{CJ}$ which "provides wrongdoers with reasons for acting that are peculiar to injurers ...to annul losses for which they are responsible." ${ }^{74}$ Perry formulates the distinctive nature of CJ in terms of outcome responsibility. He advocates for a notion of "responsibility premised on control [capacity to avoid]... [as a] normative connection between actor and outcome". ${ }^{75}$ In both Coleman's and Perry's accounts, the concepts of responsible agency and outcome responsibility explain the differential treatment of A-C and D-E coherently because they posit the "relevant principle of responsibility as 'responsibility for outcomes' not 'responsibility for acts'. 76

While both Coleman and Perry's accounts certainly provide a coherent distinction between $\mathrm{CJ}$ and DJ, it does not provide a compelling reason for maintaining the distinction if doing so compromises respecting its constitutive commitments, that of equal enforcement of responsible agency and annulment of wrongful losses. But again, their accounts deal only with how the operations of CJ are fair once something is subject to CJ. The unfairness might emerge when we step back and look at why certain cases are being sorted between the CJ and DJ machines in the first place. For us, the question is not whether we can draw a coherent distinction between CJ and DJ on the basis of a concept related to human agency, harm, or responsibility, but rather if we should want to and why. A global commitment to fairness and the negation of brute luck that it entails (again, as a way to manifest equality and responsibility), demands we do not segregate our thinking in the matter of getting people their due compensation and enforcing responsible terms of interaction. It demands we take into account the interaction between institutions and theories of DJ and CJ, not just content ourselves with answers such as "but that is a concern of distributive, not corrective justice" or visa-versa. We argue that the current theories which circumscribe corrective justice with the above mentioned concepts are under-inclusive of both the conduct and misfortunes that fairness demands we address.

\footnotetext{
${ }^{74}$ Jules Coleman, The Mixed Conception of Corrective Justice, 77 Iowa L. Rev. 427, 442 (1992).

${ }^{75}$ Perry, supra note 4, at 151.

${ }^{76}$ Coleman, Second Thought, at 312.
} 


\section{Accident Law for Egalitarians}

\section{Thick vs. Thin Concept of Personality}

Another important distinction between corrective and distributive justice is the role a concept of 'personality' plays in the respective theories. For example, in Weinrib's theory of CJ, the notion of correlativity operates on the structure of $\mathrm{CJ}$, whereas the notion of personality operates on the substantive content of the rights and duties relevant to CJ. In CJ, personality is "thin" because it merely entails that "parties are viewed as purposive beings who are not subject to a duty to act for any purpose in particular, no matter how meritorious." 77 Their only duty is a negative one- not to interfere with others' life paths. This "thin" concept is limited, according to Weinrib, only to private law. In other contexts, such as in DJ, the concept of personality is "thicker", it extends beyond the negative duties of non-interference to accommodate larger sets of duties related to the richer realms of social interactions beyond that of a specific doer and a specific sufferer. ${ }^{78}$

But, as Weinrib emphasizes, his theory of CJ does not postulate a conception of personality and then derive tort theory from it. Rather, it works backward from the doctrines and institutions of tort law to the most pervasive abstractions (correlativity and personality) implicit in it. For Weinrib, tort law is the normative practice, and personality, together with correlativity, serve as vehicles to illuminate the normative practice of tort law. ${ }^{79}$ There are no independent normative justifications for these concepts, only instrumentalist ones; together they make a coherent, but completely internal, understanding of tort law feasible. Weinrib's analysis says nothing on whether a world with tort law in it should exist; it is orthogonal to the plane on which his theory operates. He only claims that there is only one way (his way) to describe what tort law is about, he does not claim it should exist. Indeed, our main argument is that, a normative commitment to fairness less constrains the content and application of $\mathrm{CJ}$ institutions, ${ }^{80}$ as it raises doubts about the legitimacy of these institutions altogether as a way of dealing with accidents.

Peter Benson has also used the concept of personality to advance a categorical distinction of corrective from distributive justice. He has argued that "corrective justice must be viewed as

77 Weinrib, Emerging Consensus, supra note 73, at 111.

78 Id.

$79 \mathrm{Ib}$. , at 125.

80 For how commitment to fairness may constrain the content and application of CJ institutions, see Logue \& Avraham, supra note 29. 


\section{Accident Law for Egalitarians}

lexically prior to distributive justice." ${ }^{81}$ Benson, a close intellectual cousin of Weinrib's formalist conception of CJ, acknowledges that "once the initial entitlement is grounded in distributive justice... there is no need to introduce, and indeed no basis for referring to, a second, genuinely distinct form of justice such as corrective justice". ${ }^{82}$ As such, he postulates notions of entitlement and equality that are non-distributive in nature. Like Weinrib, Benson's conception of personality is thin. ${ }^{83}$ For him distributive justice takes into account various features of personality relevant for a particular criterion of distribution (such as desert, need, etc.), whereas corrective justice completely abstracts from all such features. People are not viewed as sharing in social a community, but rather as individuals who owe each other negative duties of noninterference with each other's rights. A right, in non-distributive terms is cognizable under CJ if the person "through an external manifestation of will, has brought something under his or her present and exclusive control prior to others." ${ }^{, 84}$

The duties a thin conception of personality entail can be simply characterized as: do nothing that can possibly constrain or otherwise interfere with another's rightful exercise of his or her capacity to use things, that is, with what Benson calls the other's 'abstract right' ${ }^{85}$ Benson claims this bare and minimal conception of the person is fundamentally distinct from the more complex notion of the person that underlies theories of distributive justice.

But why does Benson desire such a "thin" concept of personhood that is wholly independent of any reference to a shared conception of good or right? After all, individuals are inescapably particular, and inextricably social. Isn't it a wrong move to abstract from the reality of agency in a shared world into a hypothetical world of abstract will and abstract right, especially when we eventually need to move back into the reality of a more particular world to enforce those claims formulated in the abstract? ${ }^{86}$ Benson does not deny that agents are differentiated by their particularities, only the significance of this from a moral standpoint. Under his conception of $\mathrm{CJ}$, persons in transactions are not thought of as being members of a social

81 Peter Benson, The Basis of Corrective Justice and Its Relation to Distributive Justice, 77 Iowa L. Rev. 515, 528 (1992). $82 \mathrm{Ib}$., at 531.

83 "Whether a person has rendered or received what is due in terms of holdings can be determined without reference to the ends he or she may have, and thus independently of such considerations as intention or character which are the defining concern of the other virtues." Ib., at 535.

$84 I d$., at 543.

85 Id., at 572.

${ }^{86}$ Charles Taylor, 'Atomism', in Shlomo Avineri and Avner de-Shalit (eds.), Communitarianism and Individualism (Oxford Univ Press, 1992). 
whole, mutually related through common claims or burdens. Rather, "what persons 'share' in abstract right is simply an identical permission to use things to the exclusion of others"

But isn't it the "social whole" which enforces those rights trough its institutions? Without the "social whole" Benson's abstract rights have no practical importance. ${ }^{88}$ Having a "social whole" requires, of course, a political theory of the state, even if only a minimal state, a-la Nozick. But this just begs the question why the "social whole" should expend public resources to preserve abstract rights when doing so causes it to fail the global fairness test? We think it can do a better (egalitarian) job more globally by negating brute luck, including luck in being sorted to CJ or DJ justice machines.

Moreover, Benson justifies his "atomistic" view of agents by claiming that "the minimal condition of agents being genuinely responsible subjects is that they have the moral power to choose from a standpoint that is not tied to anything particular." 89 But why choose the "minimal condition" in the first place? Unlike in economics, where parsimonious modeling of economic behavior with the fewest possible assumptions has more than merely esthetic advantages, such as simplifying the mathematical tractability of the model, here it is hard to see the benefit of doing so. In fact, the person that Rawls and other DJ theorists have in mind looks "thin" enough to us-it only requires a very general shared notion of the good. Is all that we are left with is some esthetic admiration for a reduced form? That does not seem to justify the harsh implications in terms of global fairness. Benson and Weinrib may indeed offer an internally compelling construction of $\mathrm{CJ}$ from a thin version of personality, but there may be other ways of deriving the duties and protections we care about, ways more immediately tied to the social concerns we must ultimately face when we instituted the demands of justice in a concrete social world.

Thus, we arrive at similar point to the one we arrived with Weinrib. Benson's project is to tell us what a distinct (from DJ) concept of CJ might look like. But that does not mean such a

\footnotetext{
87 Id., at 576.

${ }^{88}$ Weinrib distinguishes two public functions- one political and the other juridical. The political function incorporates DJ concerns and is therefore inappropriate in CJ. The juridical function requires "the authoritatative specification of the form's public meaning in a particular context." Weinrib, Private Law, supra note 4 at 219. Weinrib's reply to our critique of Benson's lack of practical importance is that CJ is in fact not disconnected from the public life due to the enforcement-of-rights role of the "social whole" (as the juridical function of the public life.) Weinrib, Private Law, supra note 4 at 216-222. We just think that what Weinrib calls the 'juridical function' of the public life is still too "atomistic", it may be socially orientated yet not socially meaningful. As Coleman and Ripstein have observed and we explain below, there is no way for the authority to meaningfully specify the content's (to distinguish from the form's) public meaning without adhering to more global norms.

89 Id., at 562.
} 
concept ought to exist in order to deal fairly with people's misfortunes. Indeed, Benson himself eventually admits that even the complete absence of a CJ sphere is not a problem for his CJ theory, and that therefore it might be possible to leave no space for the operation of CJ at all. ${ }^{90}$ We think so too.

\section{Global vs. Local View of Interactions}

Another way in which corrective justice theorists talk about a necessary distinction from distributive justice is that the former elaborates principles which govern local interactions, whereas the latter elaborates principles which govern global interactions. One of the most well known theorist that sees the distinction of CJ from DJ as inherent in the different types of interaction their principles regulate is Ernest Weinrib. Again, Weinrib does not explicitly argue for creating or maintaining a distinction between CJ and DJ as theories or institutions. Rather, he claims that, on the basis of the formalist principles upon which corrective justice is elaborated, a categorical distinction in the "structures of justification" between CJ and DJ is apparent. ${ }^{91}$ Meaning that, in so far as the normative practice of tort law is structured the way it is, it is categorically distinct from DJ. CJ defines fairness in transactions, whereas distributive justice defines fairness in allocation of social burdens and benefits. For Weinrib, these two distinct principles successfully rationalize our intuitions in an exhaustive fashion in these realms. Our claim in this paper is that CJ and DJ do not fully capture all of our intuitions about fairness, (alternatively, fails to fully rationalize all our intuitions); somewhere between the cracks of CJ and DJ and RJ there is an operation of luck we find contrary to an egalitarian notion of fairness requiring treating people as equals. We now explain this in more detail.

Weinrib's distinction between $\mathrm{CJ}$ and DJ is based on the same kind of formalism that informs the content of his theory of CJ. He claims the distinction arises from a conceptual, not empirical, classification. ${ }^{92}$ In his account, DJ differs from CJ in structure not subject matter: "both forms of justice have as their subject matter the things and events that figure in external relations among persons; they differ in the structure of the operation that each performs upon

\footnotetext{
90 Benson, supra note 88, at 619.

${ }^{91}$ Ernest Weinrib, Corrective Justice in a Nutshell, 52 U. Toronto L.J. 349. Weinrib's motivation is to achieve fairness and coherence. ("Corrective justice...is an integrating idea that exhibits the meaning of coherence within a system of liability.") Id at 355. For him it is a most important normative yardstick to evaluating the law. ("Any sophisticated system of liability aspires to realize the values of fairness and coherence.") Id at 356.

92 Weinrib, Private Law, supra note 4 at 68-69. An empirical classification slices up categories according to some aspect of the physical world, such as causes, effects, etc.
} 


\section{Accident Law for Egalitarians}

those things and events." 93 Weinrib describes the differences between the structures of operation between CJ and DJ: CJ is immediate and directly links parties through the notion of correlative wrong and harm, DJ links parties in a mediated and indirect fashion. This distinction is formalized in Aristotle's description of different mathematical operations for each form of justice. He makes the distinction between CJ and DJ on two levels: the kind of equality each is designed to protect, and the respective 'structure of operations' performed to protect their distinctive kinds of equality. DJ protects geometric or proportional equality which is achieved when social resources are divided among citizens relative to some criterion or merit. CJ protects a transactional equality or 'quantitative' equality between parties to a transaction, which is the norm of behavior in the interaction in question. ${ }^{94}$

As Risptein observed, Aristole's account of DJ is a patterned theory of DJ and not a historical one. ${ }^{95}$ Aristotle's concept of DJ is static; it is about whether people's holdings are in proportion to virtue. It is not a dynamic concept concerned with how the current pattern of holdings came about. But, as we argued above, no modern political theory advances a static, patterned theory of DJ. All DJ theorists give, in one way or another, some weight to dynamic, historical, factors. ${ }^{96}$ And again, as we argued above, the historical factors that DJ theorists consider have to do with notions of responsibility that strike a balance between security and liberty. Thus, modern theories do not fit well into the Aristotelian DJ paradigm. ${ }^{97}$ From this one could conclude that: first, Aristotle's distinction, even if were relevant back then, is irrelevant today. The only thing that remained is the nomenclature "distributive justice" but it means today something else. Second, that in fact CJ and DJ are closely linked in that they are both based on the same concept of balancing liberty and security. ${ }^{98}$

But, as mentioned above Weinrib does not base the dichotomy between CJ and DJ on the subject matter they operate. Rather, Weinrib defends the Aristotelian's distinction on purely

\footnotetext{
${ }^{93}$ Id., p. 70.

${ }^{94}$ Weinrib, Private Law, supra note 4, at 62.

${ }^{95}$ We refer to Nozick's distinction between patterned and historical theories of DJ, which we discussed above, see supra note 25.

${ }^{96}$ See our discussion in section III.

${ }^{97}$ This is not to say that the Aristotelian paradigm of DJ is completely absent in current notions of DJ. Some familiar distributive justice claims-like those that contribute significantly to the general social good should be more generously compensated than those that do not—do fit into the traditional Aristotelian notion of distributive shares being proportional to merit. However, the object of our concern on the victim's side, bodily integrity, would not really be subject to this kind of reasoning. We are thankful to Charles Taylor for this point.

${ }^{98}$ Risptein, supra note 8 , at 271.
} 


\section{Accident Law for Egalitarians}

structural grounds. Indeed, in Wienrib's view corrective justice is categorically distinct from distributive justice because the former is structured by correlativity, which means it necessarily operates exclusively on the local level of interactions. Corrective justice's formal property of correlativity comes from the basic relationship of plaintiff to defendant, which in turn demands that the assessments of liability in corrective justice be limited to those considerations which are common to both plaintiff and defendant. In this sense correlativity narrows the focus to necessarily local considerations and, by definition, restricts consideration of global issues. Weinrib maintains: "no distributive considerations can serve as a justification for holding one person liable to another" and that "for purposes of justifying a determination of liability, corrective justice is independent of DJ." ${ }^{99}$ Similarly, he claims "there is a conceptual difference between the correlative logic of CJ and the comparative logic of DJ." 100

Along these same lines, Perry makes a claim about the unique nature of $\mathrm{CJ}$ when he characterizes it as addressing a "local problem", whereas DJ addresses a "global problem". $\mathrm{He}$ describes the issue as " $\mathrm{CJ}$ rectifies loss on a local scale, between two persons...the local mechanisms cannot respond satisfactorily to the global problem [of maintaining a distributive scheme]."101

In response to these arguments, we will make two claims very similar in nature to our claims above. First, that upon closer inspection corrective justice does not exclusively admit of only local considerations and correlative logic. Second, we will claim that while local versus global is an interesting distinction, it has no independent normative force that demands a divide between CJ and DJ, especially if such a divide comes at a price to treating people as equals.

Although the operations of corrective justice assessing liability and awarding compensation are structured according to a correlative, local logic, CJ also admits of comparative logic in a fundamental way. That is, in determining both which interests are protected and which actions are faulty, $\mathrm{CJ}$ must engage in the type of global accounting and distributing characteristic of DJ. In order to specify which security interests are protected, and thereby subject to compensation if transgressed, CJ must indeed take account of a global issues such as how specific interests in things (such as bodily integrity and property) allow us to lead a

\footnotetext{
${ }^{99}$ Ernest Weinrib, Corrective Justice in a Nutshell, 52, 55 Univ. of Toronto L.J. 349.

${ }^{100} I d$.

${ }^{101}$ Perry, supra note 71, at 244.
} 


\section{Accident Law for Egalitarians}

meaningful life. ${ }^{102}$ Thus, with respect to designating a specific standard of care, we need to take account of global issues to determine behavioral standards which reflect what levels of care and precautions are reasonable to expect of citizens as they go about their diverse life projects.

Coleman and Ripstein make essentially this point in their paper Mischief and Misfortune. In this paper they claim that both CJ and DJ are responses to the question of "who owns which of life's misfortunes?" and that their respective institutional embodiments both seek to "allocate misfortune and its burdens fairly." "103 Yet accounting for a fair distribution of misfortune requires an analytically prior account of the costs of activities and a general theory of what we owe each other, both of which are "normative all the way down". ${ }^{104}$ Therefore, the fault system involves global logic because, in drawing moral boundaries between persons it invokes local concepts such as "control, agency, and choice" which only make sense "in concert with substantive judgments about why various activities matter to us and about the ways in which they do."105 The fault system embodies egalitarian commitments to both fairness and equality. It is fair because it divides the risks of activities between potential plaintiffs and defendants in a way that is acceptable to both parties and it reflects equality because everyone is given a like level of security and liberty interests. However, formulating specific standards of care and selecting which interests are to be protected requires taking account of the "particular liberty interests and security interests that are at stake" and making substantive, normative arguments about the importance of those interests. 106

In conclusion, although the ideal of a unique principle of justice for local, as opposed to global, interactions is an interesting distinction, it is apparent thatCJ is not exclusively a local principle of justice at all. Indeed, with respect to some of the most important aspects of CJ, the determination of protected interests and fault, global considerations play a paramount role.

Our second point, moreover, is that nothing in a descriptive distinction between local and global interactions has normative force to generate categorically distinctive principles of justice to govern their respective realms. Indeed, the burden would be on tort theorists who make this

\footnotetext{
${ }^{102}$ Weinrib and Benson will object to this statement because for the 'thin' concept of personality they employ in their account of CJ, global issues must not be taken into account. We have raised doubts about the normative importance of their thin concept of personality above.

${ }^{103}$ Jules Coleman \& Arthur Ripstein, Mischief and Misfortune, 41 McGill L.J. 91, 94 (1995-1996) (emphasis in original).

${ }^{104} I d$., at 98.

${ }^{105} I d$., at 109.

${ }^{106} I d$., at $110-111$.
} 


\section{Accident Law for Egalitarians}

argument to explain why, if we had to design the fairest regime, would we design a regime which treats differently global versus local interactions? On the contrary, it would seem from the above discussion, global logic and assessments are central to CJ's commitment to equality. The interests that are protected by $\mathrm{CJ}$ are those which allow individual citizens to stand in relations of equality in public and private relations. To use Sen's formulation of DJ, we need to protect against wrongful loss of the capabilities necessary for citizens to participate as full, equal beings. Correspondingly, equality requires that we enforce responsibility for causing wrongful transfer so that one citizen cannot impose the costs of their activities unfairly upon others.

Agent-general vs. Agent-relative

Another familiar distinction that is pointed to as a reason for maintaining a theoretical and institutional divide between corrective and distributive justice has to do with the types of reasons each principle supplies. In his well known abandonment of the annulment thesis, Jules Coleman cites this distinction as a primary motivation for re-formulating his theory of corrective justice, least it "reduces to a form of distributive justice." ${ }^{107}$ Coleman, among others, ${ }^{108}$ claims that corrective and distributive justice are distinguished from one another on the basis of the former's agent-relative normative claims as opposed to the latter's agent-general normative claims. We will make two arguments_-again similar in nature to the ones we made above-with respect to this distinction. First, we will question if CJ produces exclusively agent-relative types of normative claims. Second, even if descriptively CJ principles generate exclusively agentrelative reasons for acting, this fact alone does not provide a convincing reason to enforce a division of labor between $\mathrm{CJ}$ and DJ, if doing so comes at a cost to fairness. After going through all this trouble, we will actually argue that the agent-relative aspect of $\mathrm{CJ}$ is a compelling feature which should be retained, albeit in a revised form, in any reconfigured approach to accident law because it both instills and reflects egalitarian values of responsibility and equality.

We now explain it in more detail. Most theorists of both CJ and DJ say that distributive justice generates agent-general reasons for action because it specifies moral or political principles defining obligations we have by virtue of membership in a community, as opposed to by virtue of a special relationship to another individual. The claims of DJ are agent-general because they apply to all members of the community equally. Corrective justice generates agent-

\footnotetext{
${ }^{107}$ Coleman, Risks, supra note 55 at 312.

${ }^{108}$ Steven Perry, Distributive Turn, supra note 4.
} 


\section{Accident Law for Egalitarians}

specific reasons for action because it specifies a duty to compensate when our actions are faulty in some appropriate way and cause harm to another person. The claims of corrective justice are agent-relative because the content of the claims are "restricted to parties who bear some important normative relationship to one another." ${ }^{, 109}$ The theoretical notions we explored earlier of outcome-responsibility, responsible agency, correlativity, and reciprocity underlie the agentspecific aspect of tort law.

However, it is inaccurate to characterized corrective justice and tort law as purely motivated by 'agent-specific' reasons. Although it enforces agent-specific obligations, the institution of tort law is motivated by elements of agent-general reasons as well. This is evident from the fact that tort law is not funded by "user fees" ${ }^{\text {"110 }}$, most modern liberal democracies devote significant public resources to providing a venue to allow individuals to pursue tort claims. If the claims of $\mathrm{CJ}$ were just the concern of the doer whom it binds and the victim whom it benefits, why not make the administrative cost of enforcement of the CJ claims an element of the liable party's damages? We conjecture that what drives the public provision of CJ institutions is that we all share some agent-general interest in the values of equality and responsibility represented and enforced by $\mathrm{CJ}$ claims.

There is an element of tort law that, like criminal law, is motivated by a general social concern for the conduct of our fellow citizens, and how such conduct affects the world we want to live in. Our agent-general concern for tort law could be characterized in several ways. First, tort law is "expressive" of both currently shared norms of behavior and a social ideal. ${ }^{111} \mathrm{We}$ want to live in a world where others take due care because they value the inherent worth of other humans. The ideal of a society of equals is expressed when people respect others as beings whose projects and goals deserve being taken into account, if not respected, as we pursue our own projects. Viewed as a whole, the duties of care in tort doctrines embody the political ideal of a civil society of equals. This would imply we have a similar concern for the behavior of both $\mathrm{D}$ and $\mathrm{E}$, despite the fact that $\mathrm{E}$ did not occasion harm to another. We are still concerned with the "social harm" E imposes, and the fact that he does not show respect for others in his actions.

\footnotetext{
${ }^{109}$ Coleman, Practice of CJ, supra note 46 at 66.

${ }^{110}$ User fees meaning an administrative fee for use of a public institution which provides private benefits, calculated based on the burden on the public resources imposed by the private parties.

${ }^{111}$ See generally, Pildes \& Anderson, Expressive Theories of Law: A General Restatement, 148 U. Penn. L. Rev. 1503 (May 2000).
} 


\section{Accident Law for Egalitarians}

Tort law not only reflects the values of equality and responsibility, it also functions to instill them. There is a sense in which we all share an interest in bringing about the state of affairs where people compensate those harms caused by their faulty action, which is an agentgeneral motivation. This desire is motivated not just by the principle of CJ-that people ought to bear these costs because of a fundamental principle of outcome responsibility, or because the fault principle points to the defendant as the appropriate bearer of these costs. It is also motivated by the notion that in such a world our fellow citizens are instilled with the social values of responsibility and prudence. ${ }^{112}$ Instilling values does not have to be reduced to deterrence in the law and economics model of calculating the appropriate level of care based on the costs of conduct. Rather, we mean instilling in the sense of reflecting in our practices a fundamental moral sense of respecting others as ends in themselves, as taking their security and liberty interest seriously as reasons for conforming our conduct to an appropriate level of care. This is the kernel we want to keep from tort law. The harm-based operation of tort law personalizes the potential consequences of our actions in a way that general maxims to 'take care' do not.

To summarize this Section, we hope we showed that the various arguments put forward in the literature for maintaining the distinction between CJ and DJ (allocation of resources vs. private wrongs, thick vs. thin view of personality, global vs. local interactions, agent general vs agent specific reason giving properties) cannot justify the distinction ex-ante, but at best can describe it ex-post. Second, and more importantly, we believe that these distinctions, even if they offered determinate analytical boundaries between CJ and DJ, should not be internally evaluated but rather be normatively evaluated and justified in the same way any human construct is evaluated-with reference to values we share. We believe that an internal justification, one that justifies a distinction only because it makes CJ (and DJ or RJ) more coherent, is not enough to justify the existence of a distinct $\mathrm{CJ}$ machine in the first place, if doing so compromises respecting the constitutive commitments of justice: fairness and equal enforcement of responsibility. Indeed, and unfortunately, viewing these distinctions as relevant does not do

\footnotetext{
112 Zipurski and Goldberg argue something similar in their paper criticizing G. Calabresi's law and economics approach to tort law for failing to understand how law in general can reinforce norms and motivate ethical behavior apart from merely incentivizing action. They argue that: "torts can be understood ... as an effort to recognize, refine, reinforce, and revise obligations that are instinct in various standard social interactions. ... it speaks the language of obligation, helping to settle, as much as possible, what is expected of a person in a range of situations." John C. P. Goldberg \& Benjamin C. Zipursky, Accidents of the Great Society, 64 Maryland Law Rev. 364 (2005).
} 
much more than maintain the separation between $\mathrm{CJ}$ and DJ or RJ as internally coherent machines of justice, yet at the expense of hurting the global production of justice. We believe this should be enough to justify revisiting traditional theories offairness in dealing with misfortunes, namely $\mathrm{CJ}$, as well as the social institutions created to manifest this theory, namely tort law.

\section{Practical Reasons: The Isolation of CJ Creates Unfair Outcomes}

Thus far we have focused on sources of luck - the agent of misfortune for victims, and the causation of harm for doers - which create unfair disparities in liability and damages at odds with the normative commitments of corrective justice thatarise s from its theoretical formulation. In addition to these sources of luck built into the theory of $\mathrm{CJ}$, there are also multiple practical operations which systematically generate unfair discrepancies in liability and compensation for otherwise similar actors. Specifically, factors such as familiarity with legal rights and recourses of the tort litigation system, acquaintance with attorneys, ability to obtain medical care to document injuries necessary to prove harm, economics of case litigation, and other related social and economic factors will all affect the compensation similarly situated accident victims receive. The relevant point we hope to touch on in this brief section is that these factors, like the luck of the draw of causation, are morally irrelevant and, whenever possible should be addressed to assure like cases are treated alike.

Before we propose a sketch of an alternative scheme, we would like to point out that tort law provides only $10 \%$ of the $\$ 500$ billion annual recoveries for accidences in the United States. Tort law therefore constitutes a relative small portion of the institutions compensating the victims of misfortune. ${ }^{113}$ Further, there is no efficient coordination of benefits between various federal programs, private insurance markets, and tort law. This problem, besides exacerbating the inefficiencies in the overall recoveries system, increases the lack of horizontal and vertical equity between similarly and differently (respectively) situated unfortunates. ${ }^{114}$

\footnotetext{
${ }^{113}$ Kenneth S. Abraham \& Lance Liebman, PRIVATE INSURANCE, SOCIAL INSURANCE, AND TORT REFORM: TOWARD A NEW VISION OF COMPENSATION FOR ILLNESS AND INJURY, 93 Colum. L. Rev. 75, 78-85. (1993)

${ }^{114}$ Id. By horizontal equity we refer to the concept that people that suffer from similar harms (with no fault of their own) should receive the same level of compensation. By vertical equity we refer to the concept that people that suffer different harms should receive different levels of compensation, in proportion to the harm suffered, and independently of the exact way it was brought about.
} 


\section{Accident Law for Egalitarians}

A particularly worrisome issue in the current tort system is that most tort victims are left outside of the CJ justice club, to change the metaphor just a bit. This of course creates a problem of under-deterrence, which we will ignore for now. Instead, we will focus on why this is a concern from an egalitarian perspective-that injured people are denied entrance to the CJ justice club, but are left with some limited access to the DJ club. There are various reasons why people are denied access to the CJ club. For example, a victim lacking information on the causal chain of the injury, difficulties proving the case in court even if the facts are known (say because of inadequate access to medical care, or if treatment of injuries were not sufficiently documented), etc. are all such reasons. These reasons make a lot of sense from an internal CJ perspective; indeed, why would someone who cannot prove her case in court (even if not her fault, but neither the defendant's) get access to the CJ club? Yet these reasons make little sense from a broader egalitarian perspective. ${ }^{115}$

Another related point is to observe who the people are who are denied access to the CJ club. Once we observe that the high costs of the current tort system (which we believe are an unavoidable consequence of the requirement of $\mathrm{CJ}$ to prove causation, prove harm, etc) prevent people with low expected recovery from receiving any $\mathrm{CJ}$ benefits at all, the answer is clear. It is those who we would worry will not get good seats in the DJ club either. Because compensation in the current tort law is based, among other things, on loss of income for the remaining working years, the low-income, the old, women, children and minorities — who on average have lower average income - are less likely to have an expected recovery that will be large enough for a lawyer to take their cases in the first place. Those who lack social networks inclusive of attorneys, are unfamiliar with the operations of insurance and tort law will also tend to be less likely to get full compensation for their injuries, because they might not pursue legitimate claims either from lack of information on how to do so, or lack of financial or time resources to do so. Moreover, low-income and high-income victims pay the same price for products, services, automobile insurance, etc.; prices of all these products and services reflect the expected loss of income in the entire pool of consumers, patients, insureds, etc. This means that, in effect, lowincome people cross-subsidize the high income people in the current tort system. ${ }^{116}$ These, in our

\footnotetext{
${ }^{115}$ For a fully developed critique of how the practical operation of tort law fails to embody the commitments of CJ, see Stepen D. Sugarman, Doing Away with Tort Law, 73 Calif. L. Rev. 558 (1985).

${ }^{116}$ To clarify this point, consider the following example. A is a high income victim and B is a low income victim, and both suffer the same injury, say, from a product that was defected. A will get much higher economic damages.
} 
view, are important pragmatic points against CJ in an institutional form segregated from that of DJ or RJ.

In practice, race, gender, and age are highly correlated with access to the CJ club. Thus, even if the CJ normative defense of the current tort system was compelling, the fact that the only way it is manifested in practice leaves so many people out of the CJ club raises questions about the legitimacy of the CJ club. The fact that those people who are left out of the CJ club are exactly that should concern us most in the DJ context just reinforces the critique. A legal system which implements notions of corrective justice such that it disproportionaly benefits those with high income in terms of both access to and benefits of the justice system, goes against basic egalitarian impulses.

Lastly, we conjecture that perhaps the fact that there is a justice club for the elite (CJ), and a separate justice club (DJ), for all the others who cannot get into the CJ club, where the bundle of benefits they can get at the DJ club is nevertheless determined by the same elite, ${ }^{117}$ may explain why this acoustic separation was stable for so many years despite its evident unfairness.

\section{Conclusion.}

In this paper we have tried to develop the simple intuition thatfairness requires, as much as possible, that like cases be treated alike. We have argued that the luck which determines dissimilar liability and compensation in our examples A-F is at odds with the egalitarian notion of fairness as equality and responsibility. We claimed that the dissimilar liability and compensation was largely due to a strict distinction between forms and institutions of justice, a distinction which fails the fairness test because it fails to confine the operation of luck to a normatively acceptable role. After surveying the arguments put forward by $\mathrm{CJ}$ theorists defending a categorical distinction of $\mathrm{CJ}$ from retributive and distributive principles, we argued that, although analytical distinctions can be made between different forms of justice, (although, we also suggest that the distinction were not as sharp some commentators suggesi there is no

\footnotetext{
But both paid the same price for the defected product (which reflected the average legal liability associated with the product). As a result B paid more than its actuarially fair price for the product and A paid less. B cross subsidized A. ${ }^{117}$ By this we mean that the benefits offered by social programs and other income transfer programs are the outcome of a political system primarily controlled by the economic elite.
} 
good reason to defend an acoustic separation between these forms of justice when doing so creates unfair outcomes.

We are not the first to observe that our distinct institutions of CJ, DJ and RJ deal in human misfortunes not so definitely distinct from one another. ${ }^{118}$ Yet, in this paper we have suggested something more. First, we have argued that, as a normative matter, egalitarians should not hold a commitment to theoretical distinctions between retributive, distributive and corrective justice as lexically prior to a global commitment to fairness. The specific unfairness we are concerned about in this paper is that some victims of misfortune are afforded massively dissimilar compensation because of irrelevant differences-the luck of the source of misfortune-and some careless actors who violate duties of care escape any assessment of liability whatsoever because of irrelevant differences - the luck of the absence of victims. The source of this unfairness is the role luck is allowed to play in sortng different cases into different institutions of justice.

Second, we have claimed that this unfairness does not arise simply because the various theories of corrective, distributive and retributive justice are imperfectly implemented in their respective institutions. Rather, we believe that many corrective justice theorists have expended unnecessary theoretical energy trying to conceptualize the demands of CJ as impervious to the principles of either retributive or distributive justice. Our intuitions about fairness in compensation for misfortunes and liability for careless actions are best captured when we integrate insights of both retributive and distributive justice in theorizing what justice demands in liability for risks and compensation for harms. This is not to say that CJ can or should be reduced to principles of either DJ or RJ. Corrective justice expresses a unique and irreducible principle of justice that captures the intuition that we are concerned with: equality in transactions and personal responsibility for actions. We are merely claiming these values are under-enforced when we limit our concern over careless action to only those cases when the actor unluckily

\footnotetext{
${ }^{118}$ For example,Weinrib has argued that "the legal regime of personal injuries can be organized either correctively or distributively. Correctively, my striking you is a tort committed by me against you, and my payment to you of damages will restore the equality disturbed by my wrong. Distributively, the same incident activates a compensation scheme that shifts resources among members of a pool of contributors and recipients in accordance with a distributive criterion. From the standpoint of Aristotle's analysis, nothing about a personal injury as such consigns it to the domain of a particular form of justice. The differentiation between the corrective and distributive justice lies not in the different subject matters to which they apply, but in the differently structured operation that each performs on a subject matter available to both.” Ernest J. Weinrib, Corrective Justice, 77 Iowa L. Rev. 403415 (1992). See also, Coleman \& Ripstein, Mischief and Misfortunes, supra note 103.
} 


\section{Accident Law for Egalitarians}

caused harm, and when we allow the luck over the source of misfortune to determine massively dissimilar compensation to otherwise identical injuries.

Another way of expressing our argument is that byrelaxing the strict bilateral, correlative structure of tort law, we can both maintain the core commitment of CJ-that of doing justice between wrongdoers and their victims-while expanding the scope of fair treatment to both unsuccessful careless doers and similarly situated blameless victims. ${ }^{119}$

Our fairness test is driven by the same impulse of fairness that drove of the minority opinion in Palsgraf v. Long Island R.R, the majority in Summers v Tice, the majority in Sindell v. Abott Laboratories: Hymowitz v. Eli lilly \& Co. ${ }^{120}$ In Paslgraf v. Long Island R.R. the negligent act of the Long Island R.R. employee in dislodging the package of fireworks caused Mrs Palsgraf's injury, but since the package was innocent looking, the effect of negligently handling it on Mrs Palsgraf could not have been reasonably anticipated. Judge Andrews argued that "where there is the unreasonable act...there is negligence whether damage does or does not result. That is immaterial". ${ }^{121}$ He then provides an example: "should we drive down Broadway at a reckless speed, we are negligent whether we strike an approaching car or miss it by an inch. The act itself is wrongful. It is a wrong not only to those who happen to be within the radius of danger, but to all who might have been there--a wrong to the public at large." ${ }^{122}$ Judge Andrews words reflect two points we mentioned earlier. First, that the occurrence of harm should not be a necessary condition for assessing liability. And, second, that careless action involves a kind of social harm, what he calls the wrong to the public at large.

In Summers $v$. Tice the plaintiff, Summers, was severely injured by a single bullet while hunting with the defendants, Tice and Simonson, who both negligently shot in his direction. He could not prove which of the two negligent hunters had actually injured him, and which had missed him. The Supreme Court of California took the innovative step of shifting the burden of proof to the defendants, Tice and Simonson, to disprove their causal contribution to Summers' injury. Because as an empirical matter it was impossible to sort out whose bullet actually hit the

\footnotetext{
${ }^{119}$ We thank Gregory Keating for this formulation of our argument.

${ }^{120}$ Palsgraf v. Long Island R.R., 248 N.Y. 339, 162 N.E. 99 (1928); Summer V Tice, 33 Cal 2d 80, 199 P.2d 1 (1948). Sindell v. Abott Laboratories, 607 P.2d 924 (Cal, 1980); Hymowitz v. Eli Lilly \& Co., 539 N.E.2d 1069 (N.Y 1989).

121 Palsgraf at 349.

${ }^{122} \mathrm{Id}$. Weinrib is right that Andrews' analysis does not make sense from an internal CJ perspective. But since we are not interested in necessarily maintaining that perspective, we believe our analysis is immune from that critique. Weinrib, Causation and Wrongdoing, 63 Chi-Kent L. Rev 407440 (1987).
} 


\section{Accident Law for Egalitarians}

defendant, the Courtin effect found them joint ly and severally liable because both were negligent. Again we see the drive to relax the strict demands of causation for a fairer result, globally understood.

Sindell was a product liability case involving the drug DES in which th daughters of mothers who took DES during pregnancy and subsequently developed cancerous vaginal and cervical growths sued various manufacturers of the generic drug. The daughters could not show which manufacturer was the actual supplier of the pills used by their mothers, and therefore the causal link between plaintiff and defendant was unspecified. The California Supreme Court held that when a substantial share of DES manufacturers are brought together as defendants market share liability is appropriate, and the burden of proof is shifted to each defendant to demonstrate that in fact they did not sell to the plaintiff's mother's drugstore. Judith Thompson posed the prescient question of why the court placed the condition that Sindell must join in her action a substantial share of the manufacturers that were riskreators ? After all, if their liability is capped in their market share, why would it matter? We think that the answer might be that the court was concerned about the unfairness in distribution of liability between similarly situated negligent actors when only some are required to pay their share, while many others are not. As Thompson explains: "if the plaintiff sues only those who manufactured...40\% of the drug, and they lose, then admittedly they pay only $40 \%$ of the plaintiff's costs; but the other who manufactured the remaining $60 \%$ of the drug have no liability imposed on them at all." ${ }^{123}$ Lastly, in Hymowitz, another DES case, the NY court ruled that each manufacturer is negligent, and that each should therefore pay according to market share it possessed at the time the mothers ingested the drug irrespective of any causal inquiry. In this way Hymowitz goes beyond Sindell, because the court held that all manufacturers should pay, even those who could show they did not cause a particular plaintiff's injury. Hymowitz demonstrates again, yet in even stronger way, the intuitive drive to hold all similarly situated wrongdoers liable for wrongful conduct at the expense of relaxing the $\mathrm{CJ}$ requirement of a causal link between doer's wrongful conduct and sufferer's harm.

\footnotetext{
${ }^{123}$ Judith Jarvis Thompson, Remarks on Causation and Liability, Philosophy and public Affairs, Vol 13(2) (1984) 101123. Thompson thinks that a better reason for that requirement is that the relevant market-share each defendant is held liable for is with respect to the total share held by the actual defendants in the lawsuit. Accordingly, if the plaintiff does not bring together substantial share of the risk, defendants might pay way more of their original market share. Thompson's interpretation of the relevant market share was later declared as incorrect, as explained by the California Supreme Court in Brown V. Superior Court of San Francisco, 751 P.2d 470 (Cal, 1988)
} 


\section{Accident Law for Egalitarians}

In sum, all these examples represent the same intuition that once someone is negligent she should bear liability, even if it the damage is too remote (as in Palsgraf), if it is not clear that the negligence act caused the damage at all (as in Summers), if it is clear thatit did not ( as in Hymowitz), or if the defendant cannot disprove her causation of harm (as in Sindell). While these intuitions about fairness in liability might not be legitimately accommodated by a CJ conception of tort law because they violate the correlative principle, they do have place in a more globally fair scheme which deals with misfortunes. Moreover, as we explained at length above, not only do we share the same fairness concerns expressed in these cases, we take it one step further and apply the same intuition to the victim's side.

Before we briefly explore possibly institutional alternatives to tort law hat fall within the zone of fairness we have tried to establish through our arguments in this paper, it is important to clarify what we have not argued. First, we do not offer an original, substantive defense of the notion that luck should not determine people's desert and responsibility. We try to show that indeed it is prevalent in DJ, RJ and CJ and we treat it as a shared normative starting point from which to build our critique. Those that do not share a commitment to negating (some) luck as way to increase fairness may not be moved by the arguments offered here. ${ }^{124}$ Second, we are not claiming that these various principles of justice—corrective, distributive and retributive — can be reduced to a "comprehensive doctrine" of fairness that can be applied in a standardized fashion to the structuring of the respective institutional forms of accident law, tax and transfer systems, and criminal law. ${ }^{125}$ Rather we argue that the notions of fair treatment developed in each cannot always be confined to that realm, and has implications for the evaluation of our practices in the other realms. Third, we do not say that a commitment to CJ as categorically distinct from DJ or $\mathrm{RJ}$ costs too much in terms of society's resources; our argument here is not that the tort system is too expensive and therefore should be abolished, although that may well be the case. The only currency we are using here is the currency of fairness. Thus, we believe we avoid issues of commensurability, because all the tradeoffs we are talking about at this stage are in terms of notions of fairness.

\footnotetext{
124 That is not to say that the precise content of a commitment to "fairness" is obvious nor non-controversial; we leave the defense of the commitment to fairness to another occasion.

${ }^{125}$ John Rawls makes a similar point regarding his conception of political justice as being limited to the subject of the major political, economic and social institutions of society: "justice as fairness is a political conception of justice: that is, it is designed for the special case of the basic structure and is not intended as a comprehensive moral doctrine." Rawls, supra note 7, at 12
} 


\section{Accident Law for Egalitarians}

Fourth, our argument is not limited to a critique of the imperfect way in which principles of corrective, distributive or retributive justice are incarnated in institutions of tort law, taxation or criminal law. Were both theories of egalitarian distributive, corrective, and retributive justice instituted perfectly, there would still be a disturbing discrepancy in the treatment of equally blameless victims and equally careless actors. This is so because theories of CJ (and DJ and RJ) remain committed to an acoustic separation between their respective principles, a separation which impairs us from hearing the costs to fairness that arises from a sorting rule in which luck plays a major role. $^{126}$

We take no view whether CJ is pre-social and therefore analytically prior to DJ, or vice versa, we think that the fair negation of luck should be prior to both. ${ }^{127}$ Put differently, we do not accept a limited role for fairness because of a lexically prior commitment to CJ, or DJ or RJ, but rather accept a limited role for CJ, RJ and DJ as developed by various theorists because we believe it serves well our lexically prior commitment to fairness.

Lastly, and most importantly, we do not argue that all losses which may be attributable to luck should be totally negated from our lives. Just as every type of misfortune (in love or cards for example) is not society's concern, every type of loss due to brute luck-the vicissitudes of nature or fortune-is not of collective, normative concern. It is not possible in practice, nor necessarily desirable in theory, to design institutions negating all losses due to luck. ${ }^{128}$ However, we think there is a relevant core of types of losses to which society has a duty to at least considering responding. We hold this includes at least losses to bodily integrity, and perhaps much more. Rawls called those core things that a reasonable person needs to live a meaningful life 'primary goods'.

\footnotetext{
${ }^{126}$ Of course, if a perfect DJ theory is implemented, such that luck is not a factor in determining peoples' life outcomes, then indeed we would not have worry about the CJ/DJ distinction. However, such a perfect DJ theory does not exist, all existing egalitarian theories call for a DJ/CJ distinction. Such a perfect theory of DJ does what we propose to do here with one difference: it calls it a theory of DJ, where we are indifferent to how one calls it. But the fact of the matter is that no one has offered such a theory of DJ. Major theorists of DJ (and CJ) have always defended a distinction between rules that apply to the "basic structure" of society, to use Rawls's term, and rules that apply to private interaction. We elaborate on this point below.

${ }_{127}$ See, Hanoch Dagan, The Distributive Foundations of Corrective Justice, 98 Mich. L. Rev. 138 (1999)

${ }^{128}$ In fact, given the objective scarcity of resources, sometime a role for luck is even required by fairness. As Arthur Ripstein points out "whether chance is arbitrary depends on how it comes to play the role that it does." To use his example, it is more fair to have random police patrols than to use racial stereotyping to police the streets. Random police patrols which apprehend only some 'unsuccessful' attempting criminals is not unfair even when such patrols miss other attempting criminals. Arthur Ripstein, supra note 4 at 12 (emphasis added).
} 


\section{Accident Law for Egalitarians}

We are not arguing that all instances of any type of careless action not resulting in harm should be subject to fines, this will require unmanageable inquiries and violations of liberty and privacy. Rather we are concerned only with those types of actions which, if harm had manifest, would result in a finding of liability. There are epistemological and normative reasons for limiting our concern to that set of careless actions. First, in terms of the normative limits of our concern, tort law already grapples with these questions of what, as a social and political community, we think is reasonable standard to expect people to conform their behavior to as a manifestation or equal respect for others security interests. The doctrines of duty of care in negligence law reflect a social determination on the normative question of what is reasonable as opposed to unreasonable risk imposition. As a general matter we find that resolution fairly satisfactory. However, the point of this paper is not to make a substantive defense of specific duties of care in tort law, but merely to say once we have established what exactly the standards of care are demanded of equal responsible citizens, there is no reason to limit our concern to only those cases where failure to live up to those standards causes harm. Second, as an epistemological matter, we agree that technical limitations on our ability to detect unsuccessful careless acts may and should limit the types of conduct we can target because the distastefulness of excessive surveillance should be an independent limitation on state action. But that is a technological-dependent matter which might well be resolved with time.

The flip side of the concern that implication of our argument entail a massive and oppressive state is that the implication of our argument entails nothing more than expanding current RJ institutions and practices, such as policing, regulatory enforcement of standards, and/or fines. Our focus in this paper is less on actual institutional design and more on the theoretical and normative reasons for changing our practices. Terming our assessment of liability to unsuccessful actors "fines" is, well, fine with us. The distinction between what we propose here in terms of financial assessments on risk creators, and traditional RJ fines, is that whereas the latter is often determine by notions of deterrence or the fiscal needs of a state, the former should be informed by notions of fairness in rectifying a wrongful act calculated in terms of social harm done and expected harm from the type of risk imposed.

Having said all that, we would like to note that we believe there might be various institutional approaches which would address the unfair role of luck we identified in liability and 
compensation. As discussed in the sections on DJ, CJ, RJ and luck, egalitarians dispute substantive notions of fairness. The question of what is properly considered brute luck as opposed to option luck is ultimately a normative question that must be hashed out in the political arena. Our argument in this paper was merely that any such system must take account not only of corrective justice principles, but also of distributive and retributive principles to assure global fairness.

Our substantive arguments about the moral similarities between equally blameless victims and equally careless actors do not dictate any specific policy approach. With respect to the cases of equally blameless victims, we believe any accident compensation scheme must assure comparable bodily harms are compensated similarly, regardless of the cause of the harm. This argument is based not on the claim that there is something essential and true about the physical similarity between injured individuals, but on a normative egalitarian commitment to assuring equal bodily integrity.

With respect to the cases of equally careless doers, we believe there would be various approaches which would fall with the "zone of fairness" 129 defined by respect for responsibility and equality. We have argued that relying on causality and harm, as does the current regime of tort law, under-enforces the values of responsibility and equality thatCJ expresses. We believe that the values of equality and responsibility, which expressed in the correlative structure of CJ ground the duty to compensate for wrongful losses, extends beyond that structure and actually has implications for fairness in compensation and liability for both blameless victims of nature and the unsuccessful wrongdoers. Whereas $\mathrm{CJ}$ theorists argue that harm is a necessary condition for liability (and harm plus fault are sufficient conditions), we distinguish between necessary and sufficient conditions for imposing liability on doers, and for compensating the victims. Thus, we argue that violation of a duty of care alone is a necessary and sufficient condition to impose some measure of liability on careless doers whereas the existence of harm, in our view, should not be a necessary condition at all in assessing liability. But that of course does not mean that the existence of harm is not important. Harm is a necessary and sufficient condition for compensating the victims, no matter what the source of the harm is, if it falls within what we called the 'core'. The level of harm is also good measure of the liability to be imposed on the

\footnotetext{
${ }^{129}$ See discussion in Section VI.
} 


\section{Accident Law for Egalitarians}

wrongdoer, although, as we argue below, certain types of "eggshell luck" might need to be eliminated there too.

Causation of harm may also be a relevant consideration for treatment of wrongdoers, yet as we argued in section $X$, violation of duties of care has normative significance independent of causation. ${ }^{130}$ We are simply arguing that as a matter of fairness we must be concerned both with careless actions that cause harm and those that luckily escape causing harm. But this does not dictate exactly what we should do with cases of unsuccessful careless drivers with respect to assessing liability because, as we have argued above, assessing the appropriate level of liability is a normative exercise in determining what is appropriate to expect of people, not discovering some fact about the world like causation or some metaphysical truth like moral blameworthiness. Therefore, we believe there is a "zone of fairness" in which various policy configurations fit the demands of respect for equality and responsibility of egalitarian commitments.

Therefore, as we have argued there are no good theoretical or normative reasons not to address the unfairness inherent in the current tort law approach to accidents. In this conclusion we would also like to suggest that there are no practical considerations to impede constucting a more fair institution of accident law which minimizes the objectionable operation of luck we identified in this paper. We do not intend our critiques to be utopian or purely theoretical. Instead we hope to offer some practical guidance towards a feasible alternative institutional design that can implement our notion of fairness. ${ }^{131}$ Of course a full account of such an institutional design is way beyond the scope of this paper, but below we present a brief sketch of a possible

\footnotetext{
${ }^{130}$ Peter Brinks makes a somewhat similar point when he argues that theorizing about tort law should refocus on its character as a civil wrong, as opposed to the remedial practices that have grown up around it such as compensation. A civil wrong "is the breach of a legal duty which affects the interest of an individual to a degree which the law regards as sufficient to allow that individual to complain on his or her own account rather than as the representative of society as a whole." Professor Brinks argues that "the content of the remedial or secondary obligation triggered by a wrong is for the law to decide as a matter of policy constrained only by extrinsic considerations...Wrongs themselves dictate no fixed measure of response." Peter Birks, The Concept of a Civil Wrong, in Philosophical Foundations of Tort Law 29-51, 51 (David G. Owen ed., 1995).

${ }^{131}$ Richard Epstein argued that no matter what the source of misfortune is, "if there were a costless way in which the consequences of bad luck could be spread across everyone in society at large, without increasing the risk of its occurrence, then most of us would pronounce ourselves better off for the change." (Richard Epstein, Luck 6 Soc. PHIL. \& POLICY 17 (1988)). In a similar manner, Christopher Schroeder argued that fairness in treating luck requires to reconsider the institution of tort law, and that there may be only practical or pragmatic reasons for doing so. Schroeder is concerned that a more DJ oriented legal scheme will hurt optimal deterrence, suffer from informational difficulties, and be overall more expensive. Christopher Schroeder, supra note 59, at 361.
} 
approach, which we think is different from approaches offered in the literature, and which we feel falls within the zone of egalitarian fairness. ${ }^{132}$

To begin with, imagine an unfortunate-compensation-fund (UCF) into which all wrongdoers pay, and from which all unfortunates receive money. ${ }^{133}$ For simplicity, we assume that it is a government managed fund; we soon relax this assumption. The UCF would be a mixed system between current tort law and a social insurance scheme which compensates the unfortunates on the basis of "lack of some equalisandum" but, simultaneously, continues to impose liability on the doer on the basis of "fault", (or perhaps even on the basis of "cause" such as strict liability. ${ }^{134}$ ) By compensating on the basis of "lack of some equalisandum" we mean that all unfortunates will be compensated for a specified set of losses to bodily integrity. Thus no matter why you are disabled, whether it is because of an accident, a disease, or the way you were born, you will be entitled to the same type and magnitude of benefits. By imposing liability on the wrongdoers on the basis of "fault," we mean that all wrongdoers will have to bear monetary responsibility for their careless conduct which imperils the security of others. Thus, in addition to regular tortfeasors, "unsuccessful" tortfeasors, also known as "risk creators," will be held monetarily accountable for their misconduct, at the level of expected harm.

Second, the UCF might compensate for the average or median loss of income in society for such injuries. (If someone wants larger coverage, she can buy it on the free marketsfor first party insurance). Thus, the UCFwill not discriminate against minorities, the elderly, women or

\footnotetext{
${ }^{132}$ One would need to compare our regime to alternative regimes proposed by other theorists like Marc Franklin, Patrick Atiyah, Christopher Schroeder and Gregory Keating to name a few in order to convince anyone about the superiority of our regime. Thus, our only goal is to suggest an economically plausible alternative system, which we believe is also more globally egalitarian. For other examples, See Marc A. Franklin, Replacing the Negligence Lottery: Compensation and Selective Reimbursement, 53 VA. L. REV. 774, 808-14 ( 1967 ); Patrick Atiyah, The Damages Lottery, (Oxford: Hart Publishing, 1997); ,Christopher Schroeder supra note 59. Gregory Keating, Rawlsian Fairness And Regime Choice In The Law Of Accidents, 72 Fordham L. Rev. 1857 (2004); Gregory Keating, Distributive And Corrective Justice In The Tort Law Of Accidents, 74 S. Cal. L. Rev. 193 (2000) ${ }^{133}$ When we say "wrongdoers" we mean individuals who violate some policy defined duty of care; "unfortunates" refers to all those who have suffered some specified class of loss to bodily integrity or perhaps even to other things society finds essential for living in a Western democratic society. See our discussion above in Section VII on equalizing bodily integrity as a "core" commitment of any egalitarian.

${ }^{134}$ See Abraham \& Leibman supra note 118 for this typology. Abraham and Leibman distinguished between fault base (tort), cause based (automobile no-fault scheme and workers' comp) and loss based (private and social insurance). Our scheme is a mixed one. On the victims' side it is a loss based. On the defendants' side it is fault based.
} 


\section{Accident Law for Egalitarians}

children. It will be age, gender and race blind in a way the current tort system is not because it provides them with similar compensation for similar injures. ${ }^{135}$

But is the UCF economically feasible? We believe that the administrative costs of the UCF might provide some savingsat least per -capita. ${ }^{136}$ In addition, by auctioning off entire classes of legal claims, (this is where we relax the assumption that it is ran by the government) we believe we can increase the competition among lawyers and thus reduce that part of the administrative costs as well. ${ }^{137}$

What about deterrence? Unlike the old regime in New Zealand where tortfeasors were not held directly monetarily accountable for their misconduct, our scheme is "mixed" in that while the unfortunates are compensated no matter the sources of their injury, the wrongdoers are held accountable. The only difference would be that the UCF will go after the wrongdoers, as opposed to individual plaintiffs. If at all, deterrence might be enhanced under a UCF like system because due to the lower administrative costs under the UCF, more people will be able to bring claims, so the problem of under-litigation of injury claims which currently hurts deterrence in the US will decrease.

The proposal offered here is not the only possible institutional design that achieves our goals of fairness, and we are not committed to defending it over any other fair alternative. Our only goal in concluding it was to show thatan alternative institutional approach is possible. Our primary goal in this paper was to demonstrate that, for those with substantive egalitarian commitments to fairness as equality and responsibility, considering such an alternative is imperative.

\footnotetext{
${ }^{135}$ See our discussion of it supra in Section VII on how the practical operation of the tort system systematically excludes certain classes of individuals.

${ }^{136}$ The no-fault automobile regimes, worker's compensation regimes, as well as the September $11^{\text {th }}$ victim compensation fund and other federal programs could serve as a source of inspiration for how thousands of losses per year could be handled at a relatively low per-capita cost.

${ }^{137}$ The idea here is that the UCF would not have to be a government fund. Instead, law firms would bid for the entire medical malpractice portfolio in Cook county Illinois in 2001-2003, for example. Law firms which offer to collect the lowest possible contingency fee will win. Such a scheme does not require lawyers to review every case before they bid; they just need to know about rough statistics. This will extract surplus form lawyers to the fund. It increases the overall pie for plaintiffs because now plaintiffs have market power. If contingency fees go down from $25 \%$ to $20 \%$, for example, this is another $5 \%$ of recoveries for Ps. There are some delicate incentives issues that need to be addressed. For example, lawyers will have to commit for a minimum amount of recovery they'll bring to the fund. (They should be allowed to purchase insurance for this). Otherwise, we might see the defendants themselves bid for, say, 5\% contingency fee and then do nothing. Commitment for a minimum recovery is a way to incentivize lawyers to work hard. Lawyers will bid just as mining companies bid for mining rights. There is a limited amount of statistics and a lot of risk, and hopefully no winner's curse.
} 